\title{
Comprehensive review about alien plants in Korea
}

\author{
Eun Su KANG, Soo-Rang LEE, Seung Hwan OH, Dong-Kap KIM, \\ Su-Young JUNG ${ }^{1}$ and Dong Chan SON*
}

Division of Forest Biodiversity, Korea National Arboretum, Pocheon 11186, Korea ${ }^{1}$ DMZ Botanic Garden, Korea National Arboretum, Yanggu 24564, Korea (Received 22 May 2020; Revised 12 June 2020; Accepted 23 June 2020)

\begin{abstract}
Species invasions have rapidly increased due to the substantial growth of global trade in the recent past. As the awareness of the negative effects on natural ecosystems derived from alien species has grown, many countries and lawmakers have enacted rules and policies on the conservation of indigenous plants. Unfortunately, in Korea, research on species invasion is seriously lacking despite the growing number of alien species. In the current study, we report alien plants that have intentionally and/or unintentionally been introduced in Korea and also presented a checklist of invasive plants found both in the literature and in field surveys. We reviewed all documented records of alien plants, i.e., scientific papers, illustrated books, and annual reports. We also categorized alien plants by origin, time of introduction, naturalization, and the rate of their spread. The results revealed that there are 619 alien plant taxa (96 families, 353 genera, 595 species, 6 subspecies, 11 varieties, 1 forma, and 6 hybrids) occurring in Korea. Among these, 30 taxa are archaeophytes (Arc.), 214 are potentially invasive plants (PIPs), and 375 are invasive alien plants (IAPs). In addition, IAP taxa consist of grades 5 (widespread, WS) to 1 (potential spread, PS) of alien plants according to the rate of spread in Korea. Our results suggested that the number of alien plants is likely to keep growing; thus, the distribution should be regularly monitored and the list of alien plants must be updated.
\end{abstract}

Keywords: Korea, alien plant, naturalization, invasive plant, checklist

국내로 유입되는 외래식물(alien plant)은 해마다 증가하 고 있다. 이들은 식용, 약용, 원예용 등 의도적인 목적을 가 지고 도입된 것이 자연생태계로 일출되기도 하지만, 대부 분 사람이나 물류가 이동하는 과정에서 함께, 혹은 인접 국가에서 해류에 떠밀려오는 등 비의도적으로 유입된다. 외래식물은 자연생태계의 변화를 야기할 뿐만 아니라 인 류의 건강 또는 경제적, 기술적인 부분 등 여러 측면에서 부정적인 영향을 미칠 수 있다(Van Wilgen et al., 2001; Pimentel, 2005; Sandvik et al., 2013; Mazza et al., 2014). 이 들이 생태계의 구성원으로서 자생종들과 어우러져 생물 다양성을 증진시킨다는 긍정적인 견해도 있지만(Lee et al., 2011), 대부분 자생종의 생육지 파괴 및 생태계 교란, 생물다양성 감소, 경관 훼손, 농작물 수확량 감소 등 부정 적인 영향이 많다는 견해가 일반적이며(Higgins et al., 1999; Pimentel et al., 2001; Liu et al., 2006; Weber et al., 2008; Gaertner et al., 2009; Rembold et al., 2017), 최근에는 기후변화에 따른 이상기후현상이 외래식물의 확산을 가
속화시킬 수 있다는 우려로 외래식물에 대한 부정적인 인 식이 더욱 늘어나고 있는 추세이다.

국내에서는 미국실새삼(Cuscuta pentagona Engelm), 돼 지풀(Ambrosia artemisiifolia L.)과 같은 외래식물의 전국적 인 확산으로 자연생태계에 부정적인 영향을 주는 사례 (Lee et al., 2015a; Oh et al., 2015; Jung et al., 2017)들이 보 고되면서 외래식물에 대한 주의를 기울이기 시작하였다. 이에 따라 외래식물을 관리하기 위한 연구와 효과적인 방 제 대책을 수립하고자 노력하고 있는 가운데 귀화식물 (naturalized plant, NP), 침입외래식물(invasive alien plant, IAP), 생태계교란식물 등 외래식물 관련 다양한 용어들이 사용되고 있다. 그러나 외래식물 관련 용어들의 정의와 범주는 정확한 기준과 체계가 수립되지 않아 연구자마다 다른 의미로 인식하거나 오용되고 있는 경우가 흔하다 (Sun et al., 2002; Hyun and Kwon, 2006). Richardson et al. (2000)은 외래식물에 대한 기준과 용어가 명확히 확립되 어 있지 않을 경우 무분별한 혼용으로 인해 외래식물의

\footnotetext{
*Author for correspondence: sdclym@korea.kr
} 
생태적 상태를 설명하거나 관리계획을 세우는 데 있어 혼 란을 초래할 수 있음을 지적한 바 있으며, 이러한 문제를 인식하고, 해결하고자 Jung (2014)은 자생식물(native plant)과 외래식물, NP, 사전귀화식물(archaeophyte, Arc.), IAP 등 외래식물 관련 용어를 정리하였으며, IAP를 유입 시기와 토착화 진행에 따라 임시귀화식물(causual naturalized plant), NP로 세분하였다. 이후 Jung et al. (2016) 은 외래식물의 유입시기, 토착화 진행, 국내 분포 여부에 따라 외래식물을 Arc., 잠재침입식물(potentially invasive plant, PIP [관심외래식물(concerned alien plant, CAP), 불확 실종(uncertain plant, UN)]), IAP (임시정착식물[casual alien plant, CAP], NP)로 체계화하였다.

우리나라의 외래식물 현황 연구는 Lee and Kim (1961)이 좀땅빈대(Euphorbia hypericifolia L.), 금달맞이꽃(Oenothera odorata L.), 달맞이꽃(Oenothera lamarckiana Seringe), 둥근잎 유홍초[Quamoclit angulata (Lam.) Bojer], 독말풀(Datura tatula Mill.), 부리새(Dactylis glomerata L.), 망초[Conyza canadensis (L.) Cronquist], 개망초[Erigeron annuus (L.) Pers.] 총 8 분류군의 $\mathrm{NP}$ 를 제시한 것으로 시작되었다. 이후 $\mathrm{Yim}$ and Jeon (1980)이 국내 200개 지역에서 27과 110분류군을, Kang and Shim (2002)은 1984년부터 국내 외래식물의 자생 지를 조사하여 재배식물을 포함한 NP 총 471 분류군을 보 고하였다. Lee et al. (2011)은 NP 321분류군을 귀화도 (naturalized degree)와 함께 목록을 보고하였고, Jung (2014) 은 IAP, NP를 포함한 다른 외래식물들의 용어 정리와 함께 IAP 290 분류군의 원산지, 개화기 등의 특징과 분포도를 작 성하였으며, Kill and Kim (2014)은 NP의 원산지와 도입되어 확산된 해외 국가 목록과 함께 총 309분류군을, Ryu et al. (2017)은 NP 326분류군의 생태형질 특성을 보고한 바 있다.

한편 최근 발견되는 외래식물은 전국 분포조사에서 발 견된 미기록 외래식물을 학계에 보고함으로서 인식되었 고, 2017년 이후 보고되고 있는 외래식물의 수는 매년 늘 어나고 있는 추세이다(Ryu et al., 2017; Kim et al., 2018; Ryu et al., 2018; Kim et al., 2019a, 2019b, 2019c). 분류군 수가 늘
어나는 원인에는 세계화 및 물류확대로 외래식물 유입 빈 도가 증가하고, 생물다양성협약(convention on biological diversity, $\mathrm{CBD}$ ) 체결 이후 자생식물 보전을 위한 외래식물 의 관심 증가, 인터넷 발달에 따른 국가간의 생물정보 공 유를 통한 외래식물 정보에 대한 접근성 용이 등으로 판 단된다(Park, 2007; Hong, 2014).

외래식물의 관리방안과 중장기계획을 세우기 위해 이 들의 현황과 유입 경로 및 생태에 미치는 구체적인 영향 을 파악해야 하지만, 그 중에서도 우선, 계속해서 새롭게 유입되는 외래식물들을 파악하여 목록을 최신화하고, 기 존에 제시되었던 목록에 대해서는 출현 여부와 분류학적 처리 여부 등으로 재검토하여 신뢰성이 있는 목록을 제시 하며, 응용이 용이하도록 체계화시키는 것이 필요하다. 미기록 외래식물의 보고는 계속해서 늘어나고 있는 반면, 이들의 현황에 관한 연구는 2017년 이후로 최신화가 이루 어지지 않았다. 기존에 보고된 외래식물의 현황목록들은 보고되었던 외래식물들의 출현 여부 및 분포변화, 새롭게 발견된 미기록 외래식물에 대한 정보를 담고 있지 않기 때문에 현재 현황 목록의 재검토 및 최신화가 이루어져야 할 시점으로 보인다.

본 연구는 국립수목원에서 수행하는 외래식물 다양성 및 위험성 평가과제 일환으로 수행된 연구결과 중 하나로, 국내 외래식물의 현황을 파악하기 위해 산림청 국립수목 원을 비롯한 타부처 외래식물 목록과 관련 주요 도감 및 연구 논문들을 재검토하여 국내 분포하는 것으로 확인된 외래식물종의 원산지와 특징을 포함한 외래식물 목록을 현행화하였다. 또한 이들 중 IAP로 분류되는 외래식물들 은 분포양상을 파악하여 확산등급을 제시하였다.

\section{재료 및 방법}

목록의 작성은 국내 외래식물 관련 문헌(Park, 2009; Lee et al., 2015b; Kim and Kil, 2017; Shin et al., 2017; Kim et al., 2018; Lee and Lee, 2018)과 논문(Ryu et al., 2017; Kim

Table 1. Type of alien plants classified by time of introductions, level of naturalization and invasion capacity.

\begin{tabular}{|c|c|c|}
\hline \multicolumn{2}{|c|}{ Type of alien plants } & Descriptions \\
\hline $\begin{array}{l}\text { Archaeophyte } \\
\text { (Arc.) }\end{array}$ & & $\begin{array}{l}\text { Localized alien plants that are presumed to have been introduced intentionally or } \\
\text { unintentionally into Korea before the opening of ports (1876), but those specific } \\
\text { introduction time and route is elusive. }\end{array}$ \\
\hline \multirow[t]{2}{*}{$\begin{array}{l}\text { Potentially invasive plant } \\
\text { (PIP) }\end{array}$} & $\begin{array}{l}\text { Concerned alien plant } \\
\text { (CAP) }\end{array}$ & $\begin{array}{l}\text { Species being intentionally introduced and cultivated, but have possibility to spread into } \\
\text { natural ecosystems. }\end{array}$ \\
\hline & $\begin{array}{l}\text { Uncertain plant } \\
\text { (UN) }\end{array}$ & Designated invasive plants that the presence in the natural ecosystems. \\
\hline \multirow[t]{2}{*}{$\begin{array}{l}\text { Invasive alien plant } \\
\text { (IAP) }\end{array}$} & $\begin{array}{l}\text { Casual alien plant } \\
\text { (CAP) }\end{array}$ & $\begin{array}{l}\text { Alien plants that just introduced and are not yet established, thus the probability of } \\
\text { naturalization and expansion are not certain. }\end{array}$ \\
\hline & $\begin{array}{l}\text { Naturalized plant } \\
\text { (NP) }\end{array}$ & $\begin{array}{l}\text { Invasive species that have been naturalized and formed a sustainable populations over } \\
10 \text { years growing naturally with the native plants. }\end{array}$ \\
\hline
\end{tabular}




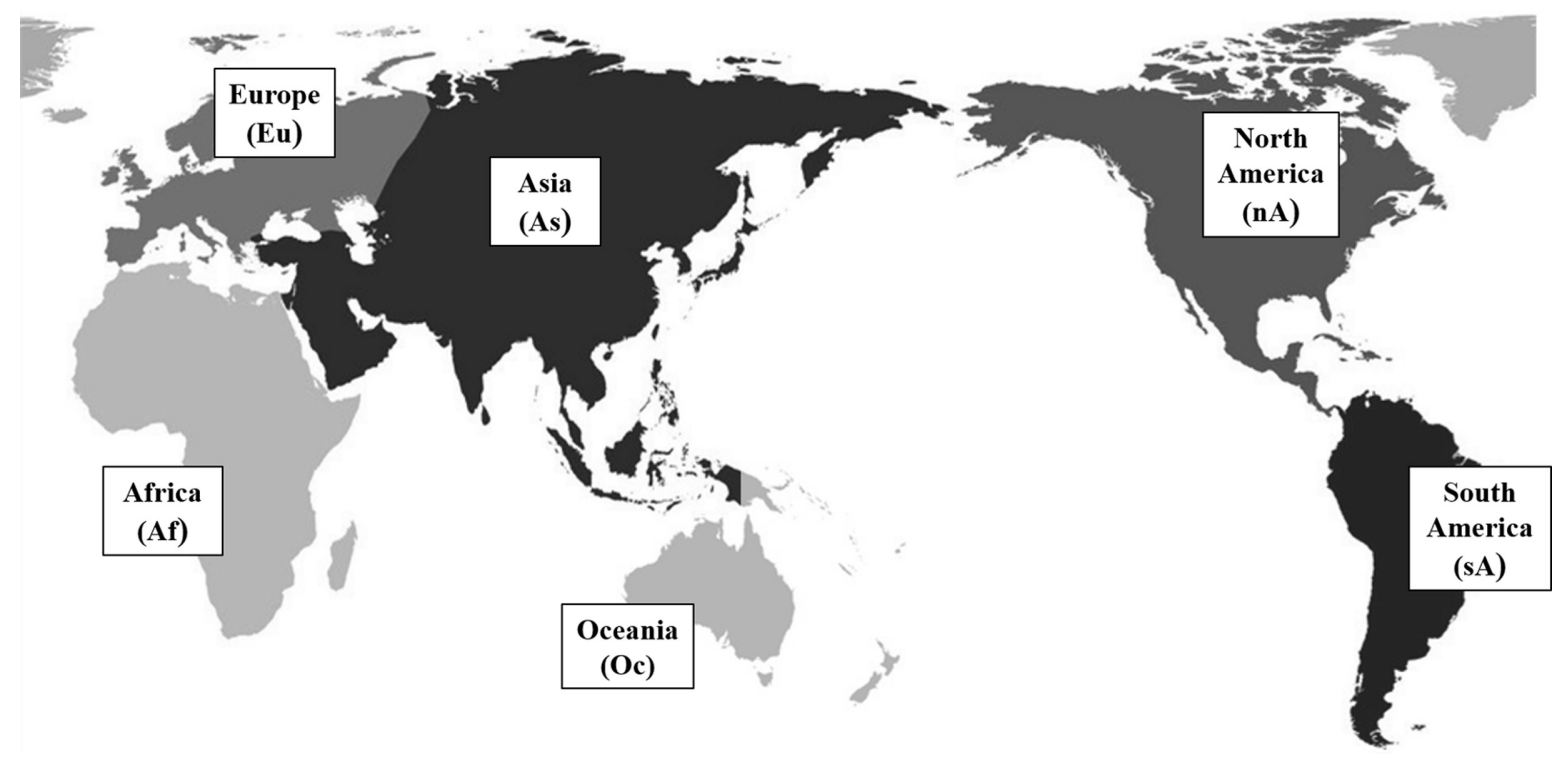

Fig. 1. Map of origins for alien plants currently occurring in Korea. The color gradients represent each of six continent. Acronyms for each region are provided in parentheses.

Table 2. Categorized level of invasiveness based on the spread rate for alien plants in Korea.

\begin{tabular}{ccccc}
\hline \hline Degree of spread & Classification & No. of places & Taxa & Rate (\%) \\
\hline V (WS) & Widespread & $>100$ & 19 & 5.07 \\
IV (SS) & Serious spread & $75-100$ & 16 & 4.27 \\
III (CS) & Concerned spread & $50-74$ & 19 & 5.07 \\
II (MS) & Minor spread & $25-49$ & 37 & 9.87 \\
I (PS) & Potential spread & $<25$ & 284 & 75.73 \\
\hline
\end{tabular}

et al., 2018; Ryu et al., 2018; Kim et al., 2019a, 2019b, 2019c), 타 부처 기관의 외래식물 목록(Lee et al., 2015b; National Institute of Biological Resources, 2019)을 조사하여 2019년 까지 국내에 분포하는 것으로 확인된 종과 일출 사례가 있거나 가능성이 높은 종을 선별한 뒤 Jung et al. (2016)의 기준에 근거해 체계적으로 분류하였고(Table 1), 이들의 생 활형 및 원산지, 유입시기를 조사하였다. 이들의 학명과 국 명은 국립수목원의 국가표준식물목록(Korea National Arboretum, 2017)과 국가표준재배식물목록(Korea National Arboretum, 2016)을 기준으로 정리하였으며, 일부 분류군 의 계급변화나 이명처리 등은 Tropicos (2019), The Plant List (2019)와 기타문헌을 참고하여 보완 및 수정하였다. 목록의 순서는 과의 경우 Engler의 분류체계에 따라 (Melchior and Werderman, 1954; Melchior, 1964) 배열하고, 과 이하의 속명, 종소명 등은 알파벳 순으로 배열하였다. 원산지는 전 세계를 6개의 대륙으로 구분하여(Fig. 1), 원 산국가가 속해 있는 대륙으로 정리하였고, 유입시기는 개 항(1876년) 전후와 분단(1945년) 전후로 나누어 분류하였 다. 또한 IAP는 시·군단위의 분포지역 수에 근거하여 국내 분포정도를 등급으로 평가하였다(Table 2, Appendix 1).

\section{결 과}

\section{국내 외래식물 현황}

국내 분포하는 외래식물은 96과 353속 595종 6아종 11변 종 1품종 6 잡종의 총 619 분류군으로 확인되었다. 이 중 양 치식물이 2 분류군 $(0.32 \%)$, 나자식물이 5 분류군 $(0.81 \%)$, 피 자식물의 쌍자엽식물이 475 분류군 $(76.74 \%)$, 단자엽식물 이 137 분류군(22.13\%)으로 구성된다(Table 3). 이들 중 높은 비율로 차지하고 있는 주요 10 과는 벼과가 100 분류군 $(16.16 \%)$ 으로 가장 많았으며, 그 다음으로 국화과가 90 분 류군(14.54\%), 십자화과 42 분류군(6.79\%), 콩과 42 분류군 (6.79\%), 석죽과 21 분류군(3.39\%), 가지과 21 분류군(3.39\%), 마디풀과 16 분류군 $(2.58 \%)$, 비름과 16 분류군 $(2.58 \%)$, 아욱 과 16 분류군 $(2.58 \%)$, 미나리과 14 분류군 $(2.26 \%)$ 으로 나타 났다(Table 4).

외래식물 목록에서 기존에 NP로 지정되었던 좀개소시 랑개비(Potentilla supina L. var. ternate Peterm)와 큰닭의덩 굴[Fallopia dentatoalata (F. Schmidt) Holub], 닭의덩굴 [Fallopia dumetorum (L.) Holub]은 동아시아와 구대륙에 넓 게 분포하고 있고, 외래식물로 판단할 수 있는 국내외 자 
Table 3. The number of alien plants in Korea

\begin{tabular}{|c|c|c|c|c|c|c|}
\hline & Species & Subspecies & Variety & Forma & Hybrid taxa & Total species and infaspecific taxa \\
\hline Pteridophytes & 2 & - & - & - & - & 2 \\
\hline Gymnosperm & 5 & - & - & - & - & 5 \\
\hline \multicolumn{7}{|l|}{ Angiosperm } \\
\hline Dicotyledons & 458 & 4 & 8 & 1 & 4 & 475 \\
\hline Monocotyledons & 130 & 2 & 3 & & 2 & 137 \\
\hline Total & 595 & 6 & 11 & 1 & 6 & 619 \\
\hline
\end{tabular}

Table 4. The number of alien plants that are in the taxonomic groups with the largest number of alien taxa by 10 th order.

\begin{tabular}{clcc}
\hline \hline & Family & Genus & Taxa (\%) \\
\hline 1 & Poaceae & 51 & $100(16.16)$ \\
2 & Asteraceae & 51 & $90(14.54)$ \\
3 & Brassicaceae & 25 & $42(6.79)$ \\
4 & Fabaceae & 22 & $42(6.79)$ \\
5 & Caryophyllaceae & 12 & $21(3.39)$ \\
6 & Solanaceae & 7 & $21(3.39)$ \\
7 & Polygonaceae & 6 & $16(2.58)$ \\
8 & Amaranthaceae & 5 & $16(2.58)$ \\
9 & Malvaceae & 9 & $16(2.58)$ \\
10 & Apiaceae & 13 & $14(2.26)$ \\
\hline
\end{tabular}

료가 미흡해 기존 원산지 표기의 착오로 판단하여 제외시 켰으며(Li and Park, 2003; Li et al., 2003; Jung, 2014; Jung et al., 2016), 분류학적 실체에 논란이 있었던 붉은양장구 채[Silene gallica L. f. quinquevulnera (L.) W. D. J. Koch], 털 들갓[Sinapis arvensis L. var. orientalis (L.) W. D. J. Koch \& $\mathrm{Ziz}$ 등의 18 분류군은 최근 분류학적 견해에 따라 이명처 리하였다(Table. 5) (Jung, 2014; Jung et al., 2016). 2018년부 터 2019년 동안 발표된 미기록종인 병풀아재비(Bowlesia incana Ruiz \& Pav.), 깃털장대(Sisymbrium irio L.), 좀전동싸 리[Melilotus indicus (L.) All.], 가는잎가시상추(Lactuca saligna L.), 나도뿔이삭풀[Hainardia cylindrica (Willd.) Greuter], 날개카나리새풀(Phalaris paradoxa L.), 주름전동 싸리(Melilotus officinalis (L.) Lam.), 꽃여뀌바늘[Ludwigia peploides (Kunth) P. H. Raven subsp. montevidensis (Spreng.)

Table 5. Summary of recent taxonomic changes for invasive alien plants in Korea.

\begin{tabular}{|c|c|c|}
\hline Family & Scientific name & Taxonomic treatment \\
\hline Caryophyllaceae & Silene gallica L. f. quinquevulnera (L.) W. D. J. Koch & Synonym of Silene gallica L. \\
\hline Cruciferae & Sinapis arvensis L. var. orientalis (L.) W. D. J. Koch \& Ziz & Synonym of Sinapis arvensis L. \\
\hline Cruciferae & Sisymbrium officinale (L.) Scop. var. leiocarpum DC. & Synonym of Sisymbrium officinale (L.) Scop. \\
\hline Rubiaceae & Diodia teres Walter var. hirsutior Fernald \& Griscom & Synonym of Diodia teres Walter \\
\hline Convolvulaceae & Ipomoea hederacea Jacq. & Synonym of Ipomoea nil (L.) Roth \\
\hline Convolvulaceae & Ipomoea hederacea Jacq. var. integriuscula A. Gray & Synonym of Ipomoea nil (L.) Roth \\
\hline Solanaceae & Datura stramonium L. var. chalybea Koch. & Synonym of Datura metel L. \\
\hline Solanaceae & Solanum photeinocarpum Nakam. \& Odash. & Synonym of Solanum americanum Mill. \\
\hline Asteraceae & Ambrosia trifida L. f. integrifolia (Muhl. ex Willd.) Fernald & Synonym of Ambrosia trifida L. \\
\hline Asteraceae & Bidens pilosa L. var. minor (Blume) Sherff & Synonym of Bidens pilosa $\mathrm{L}$. \\
\hline Asteraceae & Carduus crispus L. f. albus (Makino) Hara & Synonym of Carduus crispus L. \\
\hline Asteraceae & Conyza parva Cronquist & Synonym of Conyza canadensis (L.) Cronquist \\
\hline Poaceae & Eclipta alba (L.) Hassk. var. erecta (L.) Miq. & Synonym of Eclipta prostrata (L.) L. \\
\hline Poaceae & Bromus tectorum L. var. glabratus Spenn. & Synonym of Bromus tectorum L. \\
\hline Poaceae & Elymus repens (L.) Gould var. (Schreb. ex Baumg.) Melderis \& D. C. McClint. & Synonym of Elymus repens (L.) Gould \\
\hline Poaceae & Lolium multiflorum Lam. var. ramosum Guss. ex Arcang. & Synonym of Lolium multiflorum Lam. \\
\hline Poaceae & Paspalum distichum L. var. indutum Shinners & Synonym of Paspalum distichum $\mathrm{L}$. \\
\hline Poaceae & Sorghum halepense (L.) Pers. f. muticum (Hack.) C. E. Hubb. & Synonym of Sorghum halepense (L.) Pers. \\
\hline
\end{tabular}



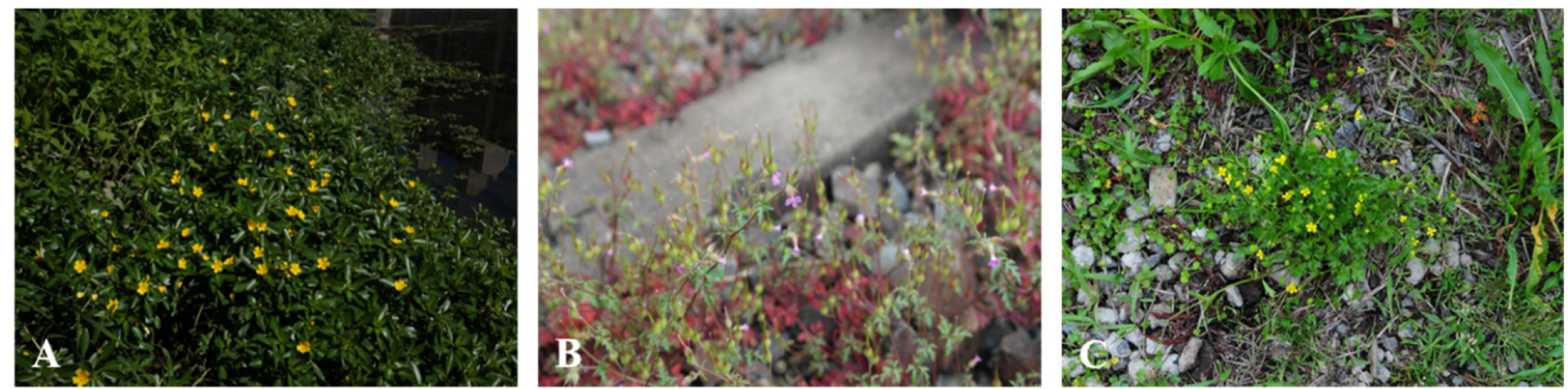

Fig. 2. Photographs of three recently reported alien plants in Korea. A. Ludwigia peploides subsp. montevidensis (Spreng.) P. H. Raven B. Geranium purpureum Vill. C. Ranunculus sardous Crantz.

P. H. Raven], 연자주쥐손이(Geranium robertianum L.), 털개 구리자리(Ranunculus sardous Crantz)의 10분류군(Fig. 2) (Ryu et al., 2017; Kim et al., 2018; Ryu et al., 2018; Kim et al., 2019a, 2019b, 2019c)과 일반적으로 재배종이지만 살비 아(Salvia officinalis L.), 페퍼민트(Mentha $\times$ piperita L.), 양 다래[Actinidia chinensis Planch. var. deliciosa (A. Chev.) A. $\mathrm{Chev]} \mathrm{등의} \mathrm{귀화목록에} \mathrm{실린} \mathrm{적이} \mathrm{있거나,} \mathrm{재배지에서} \mathrm{벗}$ 어나 야생에서 발견되어 보고된 식물들 또한 PIP의 CAP 로 분류하여 목록에 포함시켰다(Korea National Arboretum, 2016; Kim and Kil, 2017).

\section{외래식물의 분류}

국내 유입시기와 정착 여부에따라 Arc., PIP, IAP로 구분 하였다(Table 1). Arc.는 개항(1876년) 이전에 유입된 것으 로 추측되고, 자세한 유입시기 및 경로를 밝히기 어려운 토착화된 외래식물들로 자리공(Phytolacca acinosa Roxb.) 과 괭이밥(Oxalis corniculata L.) 등이 여기에 속하며, PIP는 의도적인 도입에 의해 재배되고 있지만, 자연생태계에 확 산 가능성이 있는 PIP (CAP)와 기존에 IAP이었으나, 분포 여부가 불확실한 PIP $(\mathrm{UN})$ 로 구성된다. IAP는 국내에 의 도 또는 비의도적으로 유입되어 야생화된 것으로 정착 여 부에 따라 IAP (NP)와 IAP (CAP)로 세분화하였다.

외래식물들을 상기와 같이 분류하였을 때, Arc.는 30분 류군(4.85\%), PIP는 PIP (CAP) 151분류군(24.39\%)과 PIP (UN) 63 분류군(10.18\%)으로 총 214 분류군(34.57\%)이었다. IAP는 IAP (CAP) 109분류군(17.61\%)과 IAP (NP) 266분류
군(42.97\%)의 총 375 분류군(60.58\%)으로 가장 높은 비율 을 보였다(Table 6).

생활형별로는 Arc.와 IAP에서 1-2년생이 각각 2.10\%, $35.22 \%$ 로 다년생과 목본보다 높은 비율을 차지하고 있었 고(Fig. 3), PIP는 다년생이 $21.97 \%, 1-2$ 년생이 $12.60 \%$ 으로 다년생이 더 많았다. 재배종이 주로 속하는 PIP와 달리 야

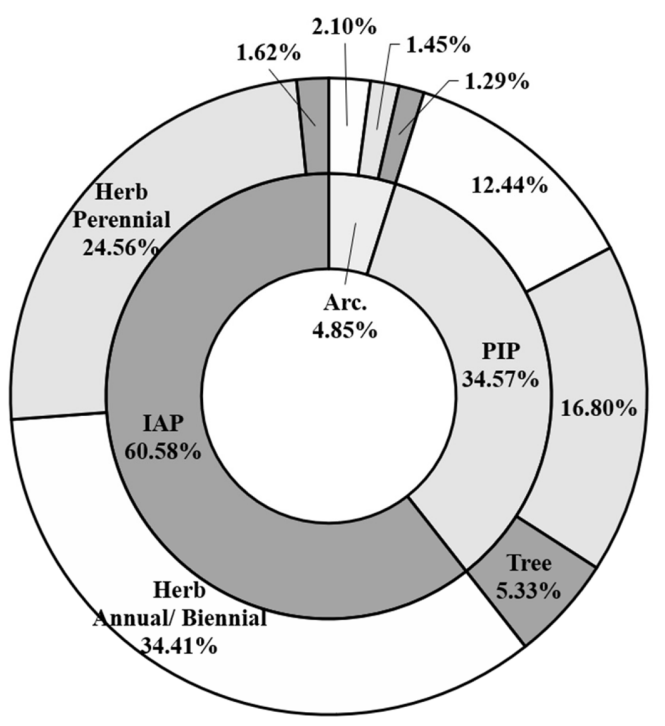

Fig. 3. Proportion of the categorized alien plant types. The inner circle shows the proportions of the classified types by time of introductions, level of naturalization and invasion capacity. The outer circle indicates the proportions of life cycle types.

Table 6. The number and proportion of alien plants classified by time of introductions, level of naturalization and invasion capacity (see Table 1 for the acronyms).

\begin{tabular}{llcc}
\hline \hline \multicolumn{1}{c}{ Type of alien plants } & & Taxa (\%) & Total (\%) \\
\hline Archaeophyte (Arc.) & & & $30(4.85)$ \\
Potentially invasive plant (PIP) & Concerned alien plant (CAP) & $151(24.39)$ & $214(34.57)$ \\
& Uncertain plant (UN) & $63(10.18)$ & $375(60.58)$ \\
Invasive alien plant (IAP) & Casual alien plant (CAP) & $109(17.61)$ & $266(42.97)$ \\
& Naturalized plant (NP) & \\
\hline
\end{tabular}




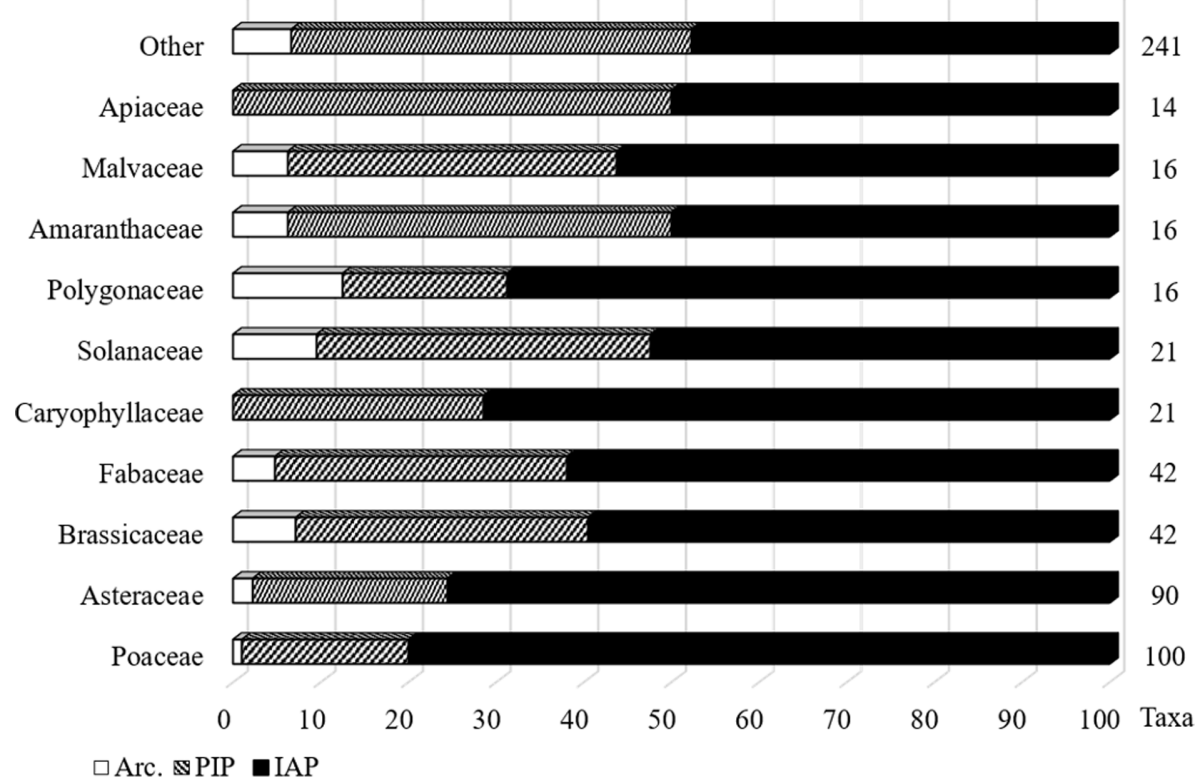

Fig. 4. Proportion of the three alien plant types (archaeophyte [Arc.], potentially invasive plants [PIPs], and invasive alien plants [IAPs]; see Table 1 for the acronyms) listed in the top ten alien species-rich families in Korea.

생화되어 있는 Arc.와 IAP의 경우 1-2년생이 높은 비율을 보이고 있어, 1-2년생이 다년생보다 다른 환경에서의 적 응 및 정착이 쉽게 일어난다는 것으로 볼 수 있다. 1-2년생 식물들은 다년생 식물들보다 짧은 생활환을 가지고 있어 환경이 열악하더라도 스트레스를 회피할 가능성이 높아 사멸될 가능성이 적으며(Lee et al., 2011), 빠른 생육과 번 식으로 수광, 무기물 등, 주위 식물과의 자원경쟁에서도 유리하여 야생화가 쉽게 일어나는 것으로 보인다.

한편 PIP에서 목본의 비율은 다른 분류들의 목본 비율 보다 높은 것을 볼 수 있으며, 이와 같은 결과는 목본 식물 이 국내에 비의도적으로 도입되어 야생화가 되는 경우보 다, 관상용 등으로 의도적으로 도입되어 식재하는 경우가 많기 때문으로 판단된다.

외래식물별로 주요 10과를 함께 보았을 때(Fig. 4), 벼과 식물이 가장 많은 분류군 수를 가질 뿐만 아니라, IAP의 비율도 $80.00 \%$ 로 가장 높았다. 이는 벼과 식물이 육지나 습지 등, 서식처의 종류가 다양하며, 알맞은 환경 조건이 갖추어졌을 경우 생육 및 번식이 빠르기 때문에 다른 과 들보다 비율이 높은 것으로 생각된다. 미나리과 식물은 $\mathrm{PIP}$ 의 비율이 $50.00 \%$ 로 다른 과들과 비교해 보았을 때 가 장 높았다. 미나리과 식물들은 옛날부터 약용, 식용으로 들여 사용해왔기 때문에 이와 같은 결과가 나온 것으로 보인다(Jung et al., 2016; Kim and Kil, 2017).

\section{원산지}

원산지별 중 아시아 원산이 $32.31 \%$ 로 가장 높았고, 그 다음으로 유럽 원산 $26.08 \%$, 북아메리카 $17.23 \%$, 남아
메리카 $12.18 \%$, 아프리카 $10.79 \%$ 오스트레일리아 $1.49 \%$ 으로 나타나 북아메리카 원산 혹은 유럽 원산의 비율이 가장 높게 나온 Lee et al. (2011), Kil and Kim (2014), Ryu et al. (2017)의 현황 조사결과와 달랐다(Fig. 5). 이는 현재까지 지속된 외래식물의 유입과 더불어 과 거의 현황이 IAP (NP)만을 대상으로 조사한 것과 달리, 본 연구에서는 IAP (NP)를 포함해 토착화 과정에 있는 외래식물 혹은 야생화되어 확산될 가능성이 있는 재배 식물을 포함하였기 때문인 것으로 보인다. 아시아 원산 이 가장 많은 이유로는 주변 국가이기 때문에 식물의 유 입이 다른 대륙들에 비해 쉽게 일어날 수 있다고 생각할 수도 있지만, 아시아와의 교류는 과거부터 현재까지 계 속 활발히 이루어지고 있을뿐만 아니라, 옛날부터 약용, 관상용으로 식물들을 많이 수입해 외래식물의 유입이 많은 것으로 보이며, 이는 아시아의 Arc.와 PIP의 비율이 다른 대륙들에서 보다 높게 나타난 것으로도 유추할 수 있다.

생활형과 함께 보았을 때, 모든 원산들에서 공통적으 로 초본의 1-2년생, 다년생, 목본 순으로 많은 것으로 나 타났으나 그 가운데, 아시아 원산의 목본 비율이 $3.95 \%$ 로 $1 \%$ 도 안되는 다른 대륙들 보다 높은 것을 알 수 있다 (Table 7). 이와 같은 결과는 옛날부터 은행나무(Ginkgo biloba L.)와 같이 중국에서 종교가 전파되면서 들어오거 나, 양버들(Populus nigra L.), 계수나무(Cercidiphyllum japonicum Siebold \& Zucc. ex J. J. Hoffm. \& J. H. Schult. bis)처럼 산림녹화용, 관상용으로 아시아 원산의 나무를 주로 들여와 식재하는 경우가 많았기 때문에 나타난 결 


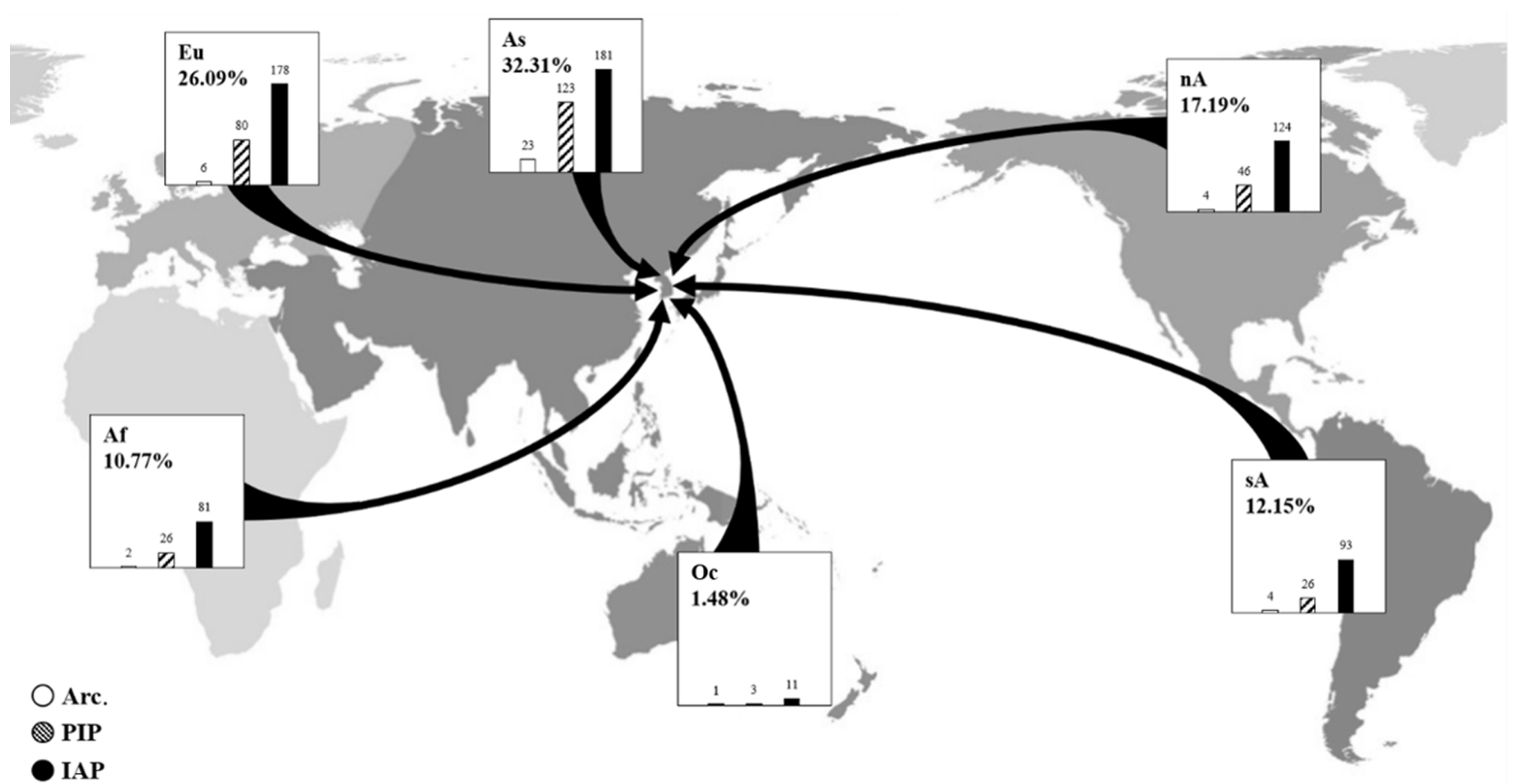

Fig. 5. Summary of alien plants occurring in Korea by the origins. The bar graphs indicate the frequencies of three alien plant types (Arc, PIPs, IAPs; see Table 1 for the acronyms).

Table 7. Proportion of alien plants originated from the six continents categorized by life-cycle types in Korea.

\begin{tabular}{|c|c|c|c|c|}
\hline & \multicolumn{2}{|c|}{ Herb (\%) } & \multirow{2}{*}{ Tree (\%) } & \multirow{2}{*}{ Total (\%) } \\
\hline & Annual/Biennial & Perennial & & \\
\hline Asia & 15.61 & 12.75 & 3.95 & 32.31 \\
\hline North America & 9.49 & 6.82 & 0.89 & 17.19 \\
\hline South America & 6.42 & 3.73 & 0 & 12.15 \\
\hline Europe & 14.92 & 10.87 & 0.30 & 26.09 \\
\hline Africa & 5.53 & 5.14 & 0.10 & 10.77 \\
\hline Oseania & 0.79 & 5.53 & 0.10 & 1.48 \\
\hline
\end{tabular}

과로 판단된다. 위 추측은 앞서 보았던 외래식물 분류에 따른 생활형에서 PIP의 목본 비율이 다른 외래식물들에 서보다 많았던 결과가 뒷받침해줄 수 있을 있을 것으로 보인다. 아시아 다음으로 많은 원산은 유럽으로, 원예종 식물들이 유럽으로부터 많이 수입되기도 하지만, Korea Customs Serviece (2020)에서 제공하는 대륙별 수출입 실 적을 보면 수출입은 북아메리카가 유럽보다 더 많은 편 이었다. 따라서 유럽의 외래식물이 직접적으로 우리나 라에 도입되는 경우보다 거리가 가까운 대륙인 아시아 나 우리나라와 교류가 많은 북아메리카를 거쳐 들어오 는 경우가 많은 것으로 보이며, 특히, 북아메리카는 과거 유럽의 식민지였던 이후로 유럽으로부터 많은 물류 이 동이 있었기 때문에 북아메리카를 거쳐 국내로 들어온 유럽 원산의 외래식물이 많을 것으로 예상된다.

\section{유입시기}

외래식물의 유입은 1876 년 개항 이전에 65 분류군 $(10.50 \%)$, 개항 이후에서 분단 이전까지 98 분류군 (15.83\%), 1945년 분단 이후 407분류군 $(65.75 \%)$ 으로 나타났다(Fig. 6). 분단 이전에는 관련 문헌이 미흡하 고, 일제강점기와 제 2 차 세계대전의 영향으로 인해 교류할 수 있는 국가가 한정되어 있어 분류군 수가 적 게 나타난 것으로 보인다. 1945년 이후에는 국내 식물 분류학 혹은 생태학과 같은 자연과학의 발달로 식생 조사가 이루어지고, 교류하는 국가 또한 증가하여 외 래식물의 발견과 유입이 많아졌기 때문에 다른 시기 들보다 분단이후 시기에서의 비율이 큰 차이로 높게 나타난 것으로 생각된다. 세계화가 진행되고 있는 현 상황에서 외래식물 유입은 앞으로도 계속될 것으로 


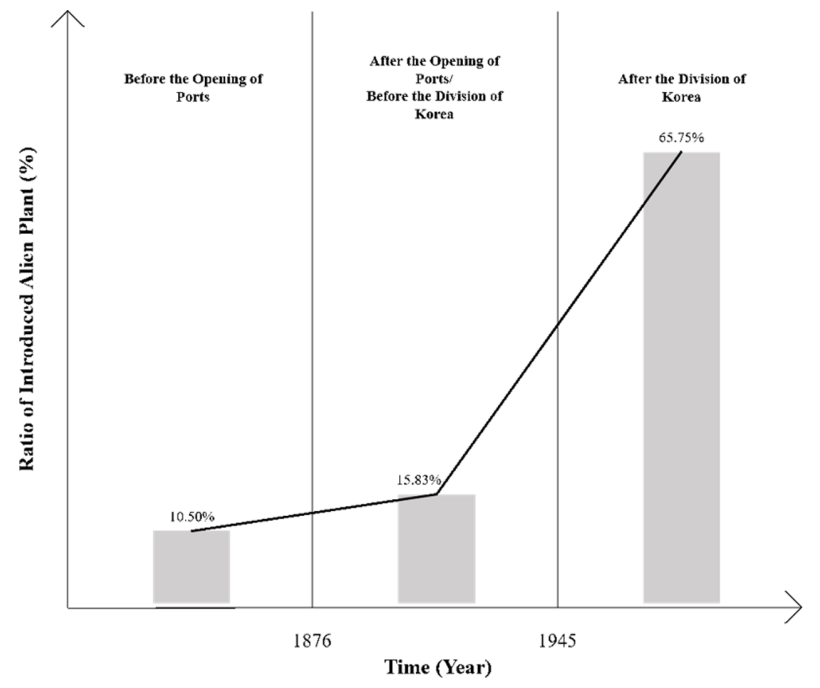

Fig. 6. Growth of alien plants introduced in Korea within the last 200 years.

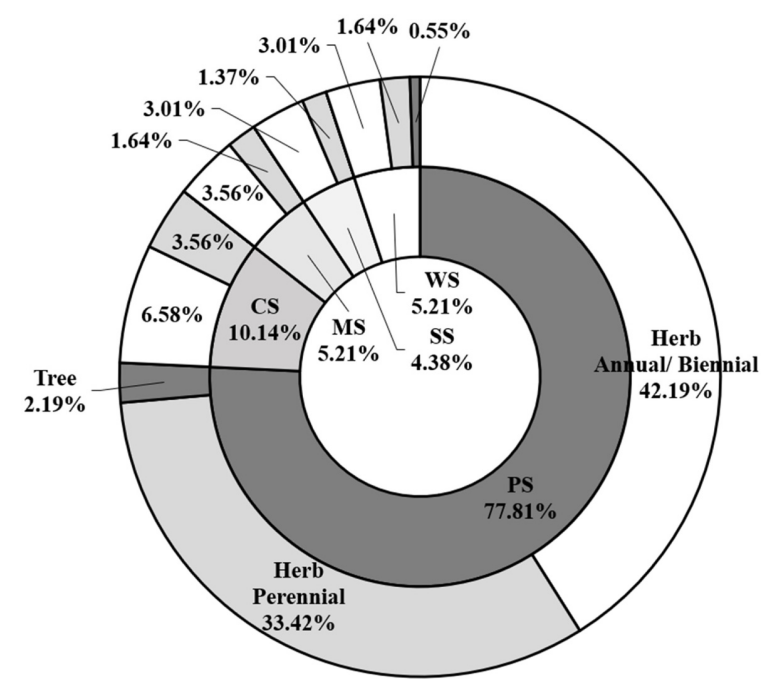

Fig. 7. Proportion of spread types across different life-cycle types. The inner circle shows the proportion of the types classified by the spread rates, while the outer circle indicates the proportion of the life cycle types for the alien species in Korea. WS, widespread; SS; serious spread; CS, concerned spread; MS, minor spread; PS, potential spread.

보이며, 유입되는 양도 지금보다 증가할 가능성이 있 는 것으로 판단된다.

\section{침입외래식물(invasive plant, IAP)의 확산정도}

외래식물의 시·군별 분포정보를 바탕으로 IAP 분류군 의 국내 분포등급을 설정하였으며, 그 결과 가장 넓은 분 포를 보이는 5 등급(widespread, WS)은 애기수영(Rumex acetosella L.), 미국자리공(Phytolacca americana L.), 좀명
아주(Chenopodium ficifolium Sm.), 족제비싸리(Amorpha fruticosa L.), 돼지풀(Ambrosia artemisiifolia L.) 등 총 19분 류군(5.07\%)이었고, 4 등급(serious spread, SS)은 16 분류군 (4.27\%), 3등급(concerned spread, CS) 19분류군(5.07\%), 2 등급(minor spread, MS) 37 분류군(9.87\%), 1 등급(potential spread, PS) 284 분류군(75.73\%)로 나타났다(Table 2). 등급 별 생활형을 보았을 때, 3 등급을 제외한 모든 등급에서 1-2년생의 비율이 높았으며(Fig. 7), 외래식물 구분에 따 른 생활형에서 본 결과와 마찬가지로 짧은 생활환을 가 지는 1-2년생 식물들이 확산에도 유리한 것으로 보인다. 목본은 5 등급과 1 등급에서만 나타났고, 5 등급은 2 분류군 $(0.55 \%), 1$ 등급에서 8 분류군 $(2.19 \%)$ 이었다. 여기서 5 등급 인 식물은 아까시나무(Robinia pseudoacacia L.)와 족제비 싸리(Amorpha fruticosa L.)이었으며(Fig. 8), 둘은 번식력 이 강한 것으로 알려진 식물일 뿐만 아니라 과거에 산림 녹화용으로 들여와 많이 식재되었으므로, 다른 목본류들 보다 국내에 넓게 확산되어 있는것으로 생각된다.

\section{침입외래식물(invasive plant, IAP)의 분포 변화}

IAP에 속하는 종들 중 과거 분포역 대비 내륙에서 확장 또는 감소 등 분포에 변화가 있거나[개양귀비; Papaver rhoeas L., 애기수영; Rumex acetosella L., 양명아주; Dysphania ambrosioides (L.) Mosyakin \& Clemants, 큰비짜 루국화; Symphyotrichum expansum (Poepp. ex Spreng.) G. L. Nesom], 제주도에 제한적인 분포를 보였던 외래식물 이 내륙으로 확장한 종[방울새풀; Briza minor L., 애기달 맞이꽃; Oenothera laciniata Hill]의 분포 및 분포등급 변화 를 보았다.

과거보다 분포역이 넓어져, 분포등급이 높아진 외래식 물은 개양귀비와 애기수영으로, 개양귀비는 1 등급 $(\mathrm{PS})$ 에 서 2 등급 $(\mathrm{CS})$, 애기수영은 3 등급(MS)에서 5 등급(WS)으로 높아졌다(Fig. 9). 개양귀비는 관상용으로 많이 심기 때문 에 자연적으로 확산되었다기보다는, 식재된 것이 관리 부 주의로 인하여 자연생태계로 일출된 경우가 많을 것을 보 이며, 이들의 종자 또한 다른 원예작물과 함께 이동되어 재배지가 아닌 곳에도 자라는 경우도 많을 것으로 생각된 다. 애기수영은 종자가 사람의 활동뿐만 아니라, 바람, 동 물 등에 의해 자연적으로 확산되기도 하며, 이 중 물에 의 해서도 확산하는 것으로 알려져 있다(Jung et al., 2015). 하 천 주변에 애기수영이 자라는 것은 많이 볼 수 있으며, 여 기서 자란 이들의 종자들이 물에 산포되고, 넓은 지역으로 확산되어 그 결과 과거에 해안가 주변으로 주로 분포하고 있던 것이 현재는 내륙뿐만 아니라 육지와 떨어진 섬까지 확산된 것으로 추측된다. 양명아주와 큰비짜루국화는 과 거에 2 등급이었으나 현재는 내륙과 북쪽지역의 분포역이 줄어들어 1 등급으로 나타났다(Fig. 10). 이는 식물의 오동 정이나 분포조사의 미흡의 결과로도 볼 수 있지만, 이들 의 생태적인 특징으로 인한 분포의 변화로도 보인다. 양 

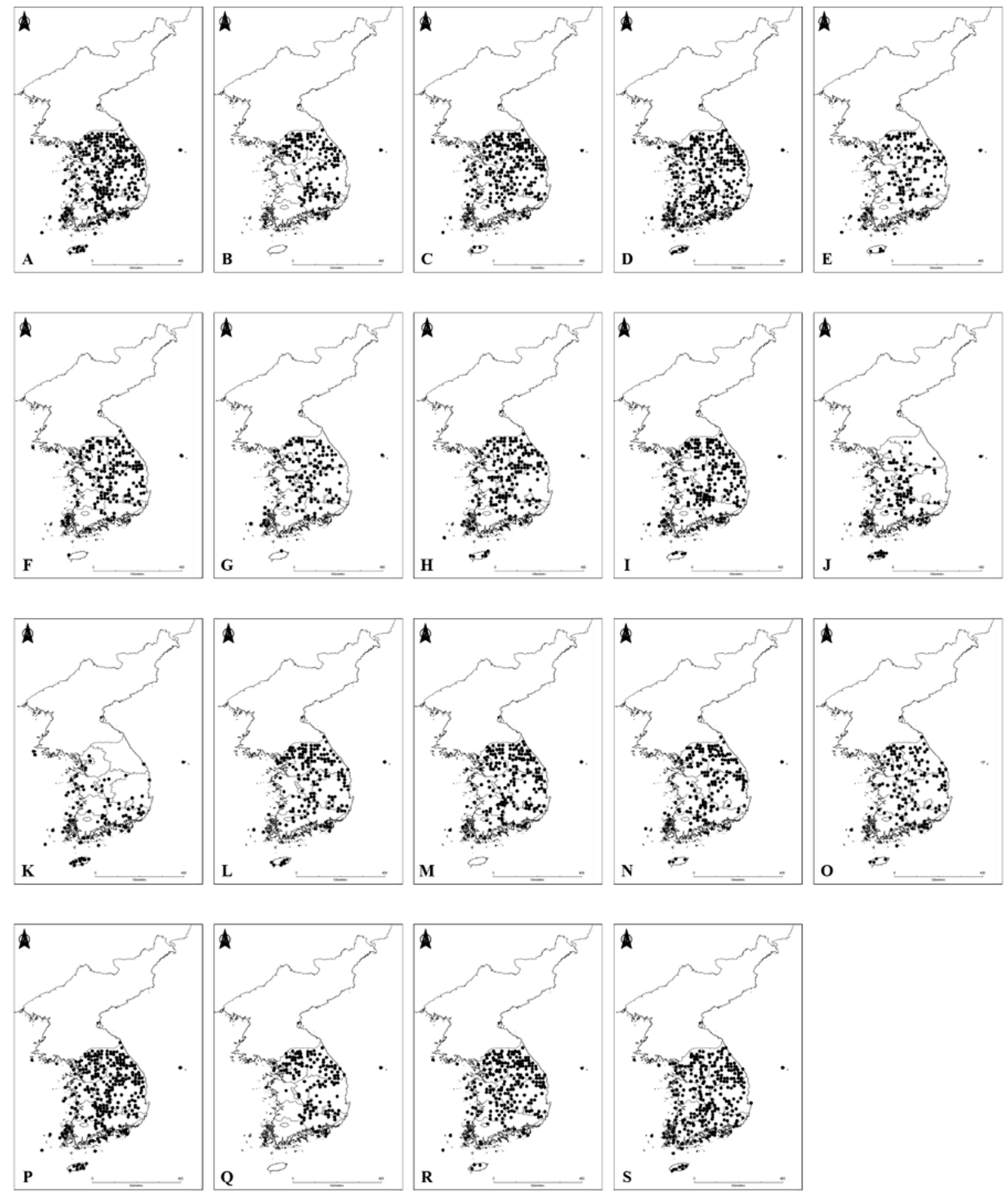

Fig. 8. Distribution of V (widespread) degree (see Table 2 for the acronym). A. Rumex acetosella L. B. Rumex crispus L. C. Phytolacca americana L. D. Stellaria media (L.) Vill. E. Chenopodium ficifolium Sm. F. Amorpha fruticosa L. G. Robinia pseudoacacia L. H. Trifolium repens L. I. Oenothera biennis L. J. Veronica arvensis L. K. Veronica persica Poir. L. Ambrosia artemisiifolia L. M. Bidens frondosa L. N. Conyza canadensis (L.) Cronquist O. Erechtites hieraciifolius (L.) Raf. ex DC. P. Erigeron annuus (L.) Pers. Q. Galinsoga quadriradiata Ruiz \& Pav. R. Taraxacum officinale F. H. Wigg. S. Dactylis glomerata L. 

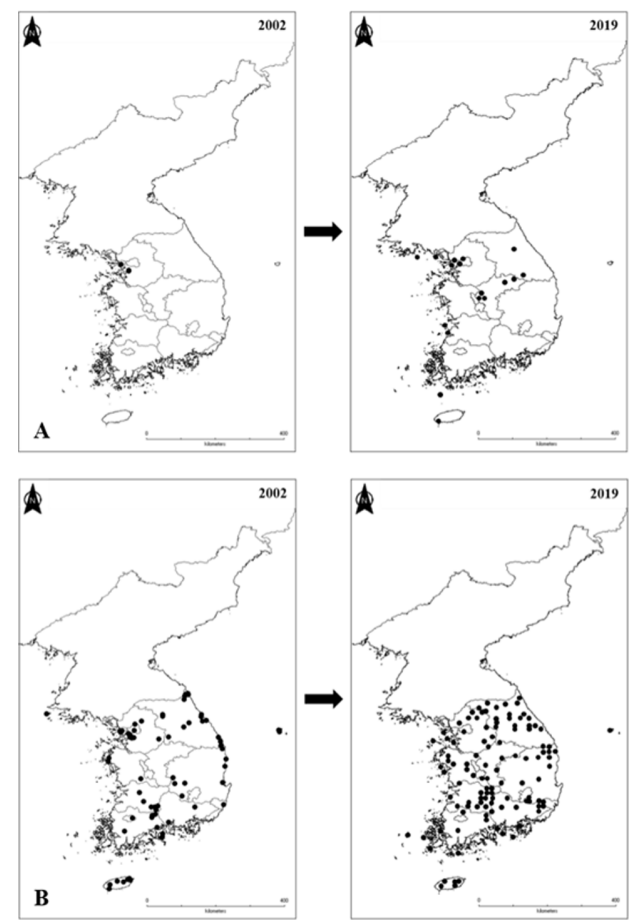

Fig. 9. Increases of distributions for two alien plants in Korea. The figures on the left represent the distributions in 2002 (Park et al., 2002), while the ones on the right represent the distributions in 2019. A. Papaver rhoeas L. B. Rumex acetosella L.
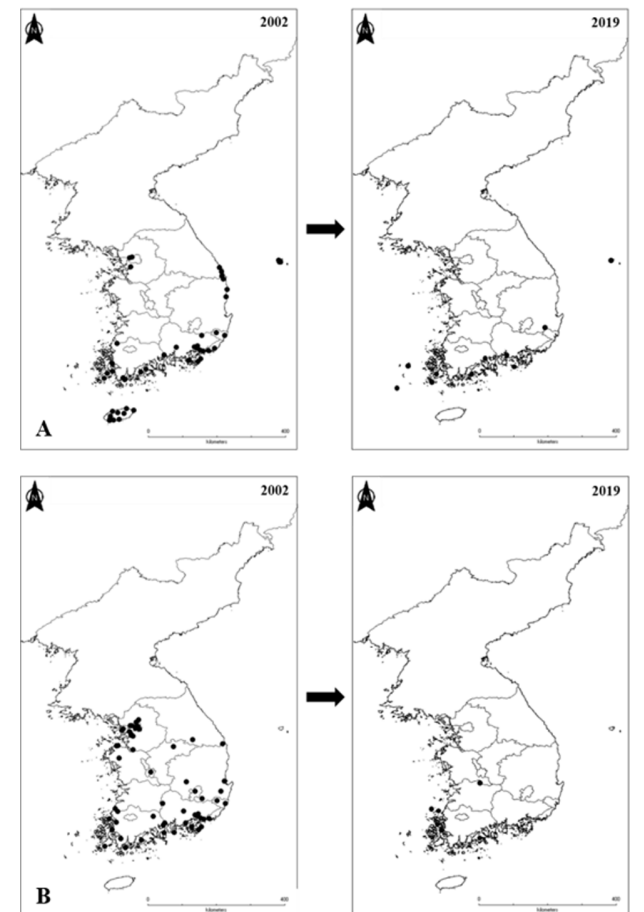

Fig. 10. Reductions of distributions of two alien plants in Korea. The figures on the left represent the distributions in 2002 (Park et al., 2002), while the ones on the right represent the distributions in 2019. A. Dysphania ambrosioides (L.) Mosyakin \& Clemants B. Symphyotrichum expansum (Poepp. ex Spreng.) G. L. Nesom.
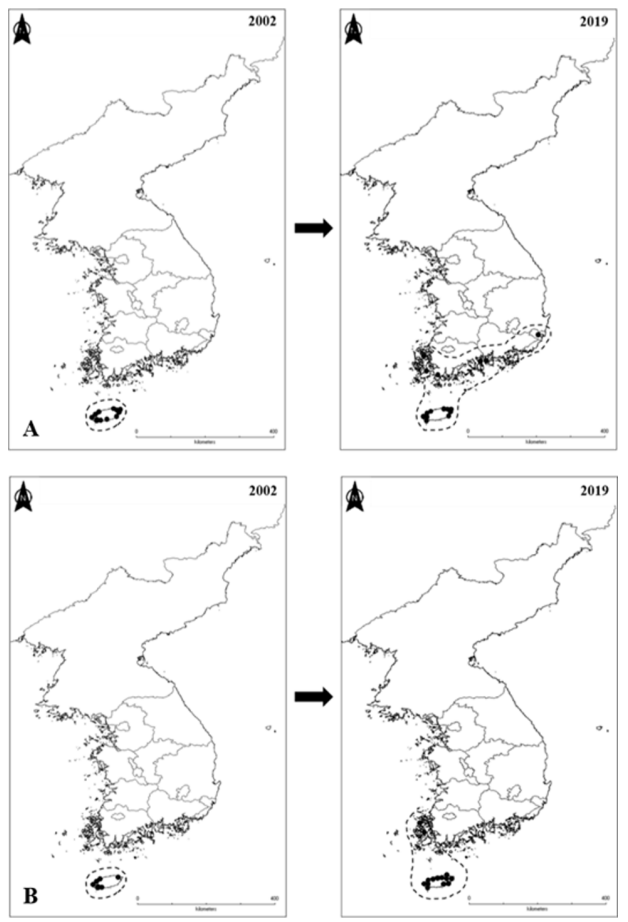

Fig. 11. Changes in the distributions of two alien plants in Korea. The figures on the left represent the distributions in 2002 (Park et al., 2002), while the ones on the right represent the distributions in 2019. A. Briza minor L. B. Oenothera laciniata Hill.

명아주와 큰비짜루국는 남아메리카와 미국의 남부지역 이 원산이며, 두 종 모두 해안이나 강과 같은 물가에서 자라는 것으로 알려져 있다. 따라서 이들의 분포는 내륙 으로 퍼지지 못하고, 북부지역에도 점차 사라져 주로 남 부지역의 해안가에만 남아있는 것으로 생각된다. 하지 만, 큰비짜루국화의 경우에는 최근에도 강화도, 경기도 에서도 발견되고 있으므로 여전히 북부지역의 해안가, 강가, 하천가에 이들의 분포지가 있는 것으로 생각된다 (Lim et al., 2014; Kim et al., 2015; Kim et al., 2018). 방 울새풀과 애기달맞이는 과거와 현재 모두 1 등급으로 분 포등급이 동일하였다(Fig. 11). 하지만, 제주도에만 국한 되어 있던 분포역이 전라남도 서해안 지역 혹은 남부 해 안지역으로 넓혀진 것을 볼 수 있었으며, 이와 같은 결 과를 볼 때, 분포등급의 결과가 과거와 현재 동일하더라 도 외래식물의 확산 가능성은 완전히 배제할 수 없을 것 으로 보인다.

위의 결과들은 외래식물의 분포역과 분포등급이 인위 적인 간섭이나 주변 환경변화에 의해 변할 수 있으며, 이 들의 정확한 분포조사 및 모니터링과 위험성 평가는 지속 적으로 진행되어야할 필요가 있다. 적절한 시기에 외래식 물의 분포변화 파악 및 확산 정도에 대한 재평가가 이루 어져, 외래식물의 효과적인 관리계획을 세우기 위한 유용 한 정보의 하나로써 제공되어야 할 것이다. 


\section{고 찰}

세계적으로 일부 외래식물들의 빠른 확산으로 인해 자생 식물의 서식처 침범과 생태계 교란을 일으키는 사례가 보고 면서 외래식물에 대한 부정적인 측면이 부각되고 있으며, 국내에서도 서양등골나물[Ageratina altissima (L.) R. M. King \& H. Rob.], 물참새피(Paspalum distichum L.), 서양금혼초 (Hypochaeris radicata L.)를 포함한 총 14종의 외래식물들이 생태계 교란종으로 지정되어 있다(Ministry of Environment, 2017). 하지만, 모든 외래식물이 생태계에 위협되는 것은 아 니며, 이들은 또한 산림과 같은 자연식생에서는 보기 드물 고, 주변 환경과 인위적 간섭에 따라 분포와 확산이 다르게 일어난다. 따라서 이들을 모두 생태계 위협대상으로만 보는 것이 아니라, 지속적인 모니터링을 통해 구체적인 정보 바 탕으로 위험성을 판단해야 될 것으로 보이며, 같은 이유로 외래식물을 효율적으로 관리하기 위해선 무조건적인 제거 방법보다 자연식생을 복원하는 방향으로 관리방안을 세우 는 것이 중요하다(Lim and Hwang, 2006; Lim et al., 2009; Lee et al., 2011). 분홍안개꽃 [Psammophiliella muralis (L.) Ikonn.], 후미 푸사선인장[Opuntia humifusa (Raf.) Raf.], 특히, 최근 전국에 많이 식재되고 있는 핑크뮬리[Muhlenbergia capillaris (Lam.) Trin.]처럼 재배하는 외래종일 경우에도 야생화 되어 생태계 에 부정적인 영향을 줄 수 있는 가능성을 내포하고 있기 때 문에 이들이 자연으로 일출되지 않도록 예방차원에서 재배 지 주변 식생을 모니터링하고 관리하는 것이 필요하다.

외래식물들의 국내 유입은 기하급수적으로 증가하고 있 으며, 이들은 새로운 지역에서 적응유무에 따라 소멸되거나 토착화가 진행된다. 환경에 의해서도 이들의 분포역이 계속 변할 수 있기 때문에 이미 귀화되었거나 소멸된 것으로 보 이는 외래식물일지라도 지속적인 현황파악을 통한 재검토 가 이루어져야 할 것이며, 신뢰성 있는 목록을 만들어 외래 식물에 관한 연구 및 관리계획을 세우기 위한 기본적인 정 보로써 제공되어야 할 것이다.

ORCID: Eun Su KANG https://orcid.org/0000-0003-34990869; Soo-Rang LEE https://orcid.org/0000-0003-0277-4926; Seung Hwan OH https://orcid.org/0000-0003-2190-0967; DongKap KIM https://orcid.org/0000-0002-6451-2035; Su-Young JUNG https://orcid.org/0000-0002-6755-1072; Dong Chan SON https://orcid.org/0000-0002-6773-0580

\section{Conflict of Interest}

The authors declare that threr are no conflicts of interest.

\section{Literature Cited}

Gaertner, M., A. Den Breeyen, C. Hui and D. M. Richardson.
2009. Impacts of alien plant invasions on species richness in Mediterranean-type ecosystems: a meta-analysis. Progress in Physical Geography 33: 319-338.

Higgins, S. I., D. M. Richardson, R. M. Cowling and T. H. Trinder-Smith. 1999. Predicting the landscape-scale distribution of alien plants and their threat to plant diversity. Conservation Biology 13: 303-313.

Hong, S. K. 2014. A convention on biological diversity, insland biodiversity and strategy of Korea. Journal of Korean Island 26: 187-202. (in Korean)

Hyun, J. O. and S. K. Kwon. 2006. Flora of Dokdo. Report on the Detailed Survey of Dokdo Ecosystem. Ministry of Environment, Seoul. Pp. 35-44. (in Korean)

IPNI. 2019. International Plant Names index. Published on the Internet. Retrieved Dec. 10, 2019, available from http:// www.theplantlist.org.

Jung, J. M., S. Y. Jung, S. H. Park, J. C. Yang. G. Choi, S. W. Oh and C. H. Shin. 2015. Invasive Alien Plant Impact on Forest. Korea National Arboretum, Pocheon, 280 pp. (in Korean)

Jung, S. Y. 2014. A study on the distribution characteristics of Invasive Alien Plant (IAP) in South Korea. PhD dissertation, Andong National University, Andong, 234 pp. (in Korean).

Jung, S. Y., J. W. Lee, Y. H. Kwon, H. T. Shin, S. J. Kim, J. B. An and T. I. Heo. 2016. Invasive Alien Plants in South Korea. Korea National Arboretum, Pocheon, 265 pp. (in Korean)

Jung, Y.-H., J.-K. Lee, S.-I. Lee, S.-Y. Lee, R.-H. Jang, S.-H. Lee, K.-T. Cho and Y.-H. You. 2017. Host plant preference, parasitic site and risk possibility of Cuscuta pentagona Engelm, invasive plant in Korea. Korean Journal of Enviromental Ecology 31: 287-296. (in Korean)

Kang, B. H. and S. I. Shim. 2002. Overall status of naturalized plants in Korea. Korean Journal of Weed Science 22: 207226.

Kill, J. and C.-G. Kim. 2014. Current status of naturalization by exotic ornamental plants in Korea. Weed \& Turfgrass Science 3: 206-214. (in Korean)

Kim, C. -G. and J. Kil. 2017. Alien Flora of the Korean Peninsula. Econature, Seoul, 655 pp. (in Korean)

Kim, H.-W, D. C. Son, S. H. Park, C.-S. Jang, E.-M. Sun, H. Jo, S. M. Yun and K. S. Chang. 2019a. Unrecorded alien plant in south Korea: Ludwigia peploides subsp. Montevidensis (Spreng.) P.H. Raven. Korean Journal of Plant Resources 32: 201-206. (in Korean)

Kim, H.-W., E.-M. Sun, S.-Y. Jung and D. C. Son. 2019b. Geranium purpureum Vill.: a new casual alien plant in Korea. Korean Journal of Plant Taxonomy 49: 209-214.

Kim, J.-H., S.-A. Park and C.-Y. Yoon. 2018. Floristic study of Deokjeongsan Mt. (Ganghwa-gun), Korea. Korean Journal of 
Plant Resources 31: 149-161. (in Korean)

Kim, J.-H., S.-Y. Kim, C.-Y. Yoon, S.-A. Park and Y.-H. Kim. 2015. Floristic study of Mt. Byeollipsan (Ganghwa-gun), Korea. Korean Journal of Plant Resources 28: 441-455. (in Korean)

Kim, J. O., T. B. Ryu, M. J. Kim, D. H. Kim and N. S. Lee. 2019c. Two unrecorded alien plants of genus Melilotus in Korea: $M$. officinalis and M. indicus (Leguminosae). Korean Journal of Plant Resources 32: 63-71. (in Korean)

Korea Customs Serviece. 2020. Export and import performance by continent. Retrieved Mar. 10, 2020, available from https://unipass.customs.go.kr/ets/index.do?menuId=ETS_MNU_00000110.

Korea National Arboretum. 2016. Standard Checklist of Cultivated Plants in Korea. Korea National Arboretum, Pocheon, 510 pp. (in Korean)

Korea National Arboretum. 2017. Checklist of Vascular Plants in Korea. Korea National Arboretum, Pocheon, 1000 pp. (in Korean)

Lee, C. S. and K. H. Lee. 2018. Pteridophytes og Korea: Lycophytes \& Ferns. Geobook, Seoul, Pp. 146-147.

Lee, C. W., D. Kim, H. Cho and H. Lee. 2015a. The riparian vegetation disturbed by two invasive alien plants, Sicyos angulatus and Paspalum distichum var. indutum in South Korea. Ecology and Resilient Infrastructure 2: 255-263. (in Korean)

Lee, D. B. and Y. C. Kim. 1961. A historical review of some plants of American origin in Korea. Journal of Plant Biology 4: 2529. (in Korean)

Lee, H. H. M., D. E. Kim, D. H. Lee, S. H. Kim, C. W. Lee, D. H. Choi, H. J. Lee, H. M. Kim, Y. C. Kim, M. J. Kim, D. Kim and H. R. Song. 2015b. Alien Species in Jeju Island, Korea. National Institute of Ecology, Seocheon, 160 pp. (in Korean)

Lee, Y.-M., S.-H. Park, S.-Y. Jung, S.-H. Oh and J.-C. Yang. 2011. Study on the current status of naturalized plants in South Korea. Korean Journal of Plant Taxonomy 41: 87-101. (in Korean)

Li, A. R. and C. W. Park. 2003. Fallopia. In Flora of China. Vol. 5 (Ulmaceae through Basellaceae). Wu, Z. Y., P. H. Raven and D. Y. Hong (eds.), Science Press, Beijing and Missouri Botanical Garden Press, St. Louis, MO. pp. 315-318.

Li, C. L., H. Ikeda and H. Ohba. 2003. Potentilla. In Flora of China. Vol. 9 (Pittosporaceae through Connaraceae). Wu, Z. Y., P. H. Raven and D. Y. Hong (eds.), Science Press, Beijing and Missouri Botanical Garden Press, St. Louis, MO. pp. 291327.

Lim, D.-O. and I.-C. Hwang. 2006. Exotic plants and conservation in Gayasan National Park. Korean Journal of Environment and Ecology 20: 281-288. (in Korean)
Lim, D.-O., H.-S. Kim and M.-S. Park. 2009. Distribution and management of naturalized plants in the northern area of south Jeolla Province, Korea. Korean Journal of Environment and Ecology 23: 506-515. (in Korean)

Lim, Y., K.-P. Yoo, The Korean Society of Plant Parataxonomists and J.-O. Hyun. 2014. Floristic study of Daebudo Island. Korean Journal of Plant Resources 27: 447-476. (in Korean)

Liu, J., M. Dong, S. L. Miao, Z. Y. Li, M. H. Song and R. Q. Wang. 2006. Invasive alien plants in China: role of clonality and geographical origin. Biological Invasions 8: 1461-1470.

Mazza, G., E. Tricarico, P Genovesi and F. Gherardi. 2014. Biological invaders are threats to human health: an overview. Ethology Ecology and Evolution 26: 112-129.

Melchior, H. 1964. A. Engler's Syllabus der Pflanzenfamilien, 12. Angiospermen. Gebruder Borntraeger, Berlin, 666 pp.

Melchior, H. and E. Werderman. 1954. A Engler's Syllabus der Pflanzenfamilien. Gebruder Borntraeger, Berlin, 367 pp.

Ministry of Environment. 2017. Invasive Alien Species. Retrived Mar. 10, 2020, available from http://www.me.go.kr/home/ web/public_info/read.do;jsessionid=xsTXmyY6FCNENKmq VloVjLII0gCQ2CDP2XztvGugN30XI1Yh04wIH7IFVnjA3 oTs.meweb1vhost_servlet_engine1?pagerOffset $=0 \&$ maxPage Items $=10 \&$ maxIndexPages $=10 \&$ searchKey $=\&$ searchValue $=$ \&menuId=10357\&orgCd=\&condition.publicInfoMasterId= $5 \&$ condition.deleteYn=N\&publicInfoId $=777 \&$ menuId $=10357$

National Institute of Biological Resources. 2019. National Species list of Korea. I. Plants, Fungi, Algae, Prokaryotes. National Institute of Biological Resources, Incheon, 924 pp. (in Korean)

Oh, D., D. Shim, S. Song, J. Oh, S. Hong and S. Shim. 2015. Effects of soil moisture condition and shading on growth of invasive plant burcucumber (Sicyos angulatus L.). Weed \& Turfgrass Science 4: 315-320.

Park, S. H. 2009. New Illustrations and Photographs of Naturalized Plant of Korea. Ilchokak, Seoul, 575 pp. (in Korean)

Park, S. H., J. H. Shin, Y. M. Lee, J. H. Lim and J. S. Moon. 2002 Distributions of Naturalized Alien Plants in Korea. Ukgo Press, Seoul. 184 pp. (in Korea)

Park, Y.-H. 2007. Analysis of a cross-cutting issue, 'access to genetic resources and benefit-sharing' of the conference of the parties to the convention on biological diversity. Journal of Environmental Policy 6: 41-60. (in Korean)

Pimentel, D. 2005. Environmental consequences and economic costs of alien species. In Invasive Plants: Ecological and Agricultural Aspects. Inderjit, S. (ed.), Birkhäuser, Basel. Pp. 269276.

Pimentel, D., S. McNair, J. Janecka, J. Wightman, C. Simmonds, C. O’Connell, E. Wong, L. Russel, J. Zern, T. Aquino and T. Tsomondo. 2001. Economic and environmental threats of 
alien plant, animal, and microbe invasions. Agriculture, Ecosystems and Environment 84: 1-20.

Rembold, K., H. Mangopo, S. S. Tjitrosoedirdjo and H. Kreft. 2017. Plant diversity, forest dependency, and alien plant invasions in tropical agricultural landscapes. Biological Conservation 213: 234-242.

Richardson, D. M., P. Pyšek, M. Rejmánek, M. G. Barbour, F. D. Panetta and C. J. West. 2000. Naturalization and invasion of alien plants: concepts and definitions. Diversity and Distributions 6: 93-107.

Ryu, T.-B., J.-W. Kim and S.-E. Lee. 2017. The exotic flora of Korea: actual list of neophytes and their ecological characteristics. Korean Journal of Environment Ecology 31: 365-380. (in Korean)

Ryu, T.-B., S.-E. Lee, D. Kim, D.-H. Choi and N.-Y. Kim. 2018. An unrecorded alien species in Korea: Phalaris paradoxa $\mathrm{L}$. (Poaceae). Korean Journal of Plant Resources 31: 52-55. (in Korean)

Sandvik, H., B.-E. Sæther, T. Holmern, J. Tufto, S. Engen and H. E. Roy. 2013. Generic ecological impact assessments of alien species in Norway: a semi-quantitative set of criteria. Biodiversity and Conservation 22: 37-62.
Shin, H. T., S. Y. Jung, H. C. Kim, J. H. Lee, J. S. Choi, S. J. Kim, J. B. An, T. I. Heo and J. W. Lee. 2017. Invasive Alien Plants on DMZ. Korea National Arboretum, Pochen, 295pp. (in Korean)

Sun, B.-Y., M. R. Sul, J. A. Im, C. H. Kim and T. J. Kim. 2002. Evolution of endemic vascular plants of Ulleungdo and Dokdo in Korea: floristic and cytotaxonomic characteristics of vascular flora of Dokdo. Korean Journal of Plant Taxonomy 32: 143-158. (in Korean)

Tropicos. 2019. Missouri Botanical Garden. Retrieved Dec. 10, 2019, available from https://www.tropicos.org.

Van Wilgen, B. W., D. M. Richardson, D. C. Le Maitre, C. Marais and D. Magadlela. 2001. The economic consequences of alien plant invasions: examples of impacts and approaches to sustainable management in south Africa. Environment, Development and Sustainability 3: 145-168.

Weber, E., S.-G. Sun and B. Li. 2008. Invasive alien plants in China: diversity and ecological insights. Biological Invasions 10: 1411-1429.

Yim, Y. J. and E. S. Jeon. 1980. Distribution of naturalized plants in the Korean peninsula. Korean Journal of Plant Biology 23: 69-83. (in Korean)

\section{국내 외래식물의 현황}

\section{강은수 · 이수랑 - 오승환 - 김동갑 - 정수영 ${ }^{1}$ 손동찬}

국립수목원 산림생물다양성연구과, ${ }^{1}$ 국립수목원 DMZ자생식물연구과

적 요: 세계화에 따른 국제교류가 증가함에 따라 외래식물의 국내 유입 또한 증가하고 있다. 외래식물이 자 연생태계에 미칠 수 있는 여러 부정적인 영향들이 알려지면서 전 세계적으로 자생식물의 보전을 위한 국가 차원의 관리 및 여러 정책들이 수행되고 있지만, 국내의 경우 이들의 현황 파악조차 미흡한 실정이다. 본 연 구는 국립수목원에서 수행하는 '외래식물 다양성 변화 및 위험성 평가' 과제의 일환으로 수행된 연구결과 중 일부로, 국내에 유입되어 정착화되었거나, 재배지로부터 일출되어 자연생태계로 확산 가능성이 높은 외래식 물의 현황을 파악하였고, 산림청 국립수목원을 비롯한 타부처 외래식물 목록과 관련 주요 도감 및 문헌들을 재검토하였다. 또한 이들을 원산지, 도입시기 및 정착 여부에 따라 체계화하였고, 침입외래식물로 분류되는 외래식물들은 국내 분포정보를 바탕으로 확산정도를 등급화 하였다. 그 결과 국내에 분포하는 외래식물은 96과 353속, 595종, 6아종, 11변종, 1품종, 6잡종의 총 619분류군으로 파악되었으며, 이 중 사전귀화식물 30 분류군, 잠재침입식물 214분류군이었고, 침입외래식물은 총 375 분류군으로 5 등급(widespread, WS)이 19분류 군, 4등급(serious spread, SS) 16분류군, 3등급(concerned spread, CS) 19분류군, 2등급(minor spread, MS) 37분 류군, 1 등급(potential spread, PS) 284분류군으로 나타났다. 외래식물은 앞으로도 계속 유입될 것이고, 이들의 분포 또한 환경 및 기타요인에 의해 변하기 때문에 지속적인 현황파악이 수행되어야 한다.

주요어: 국내, 외래식물, 귀화, 침입외래식물, 현황 
Appendix 1. Checklist of alien plants in Korea.

\begin{tabular}{|c|c|c|c|c|}
\hline List & L-f & Orig. & Type of alien plant & Degree \\
\hline \multicolumn{5}{|l|}{ Salviniaceae 생이가래과 } \\
\hline 1. Azolla cristata Kaulf. 좀물개구리밥 & Pe. & sA & $\mathrm{IAP}(\mathrm{CAP})$ & PS \\
\hline 2. Azolla filiculoides Lam. 주름물개구리밥 & Pe. & $\mathrm{nA}, \mathrm{sA}$ & $\mathrm{IAP}(\mathrm{CAP})$ & PS \\
\hline \multicolumn{5}{|l|}{ Ginkgoaceae 은행나무과 } \\
\hline 3. Ginkgo biloba L. 은행나무 & Tr. & As & Arc. & \\
\hline \multicolumn{5}{|l|}{ Pinaceae 소나무과 } \\
\hline 4. Larix kaempferi (Lamb.) Carrière 일 본잎갈나무 & Tr. & As & PIP (CAP) & \\
\hline 5. Pinus rigida Mill. 리기다소나무 & Tr. & $\mathrm{nA}$ & PIP (CAP) & \\
\hline \multicolumn{5}{|l|}{ Cupressaceae 측백나무과 } \\
\hline 6. Chamaecyparis obtusa (Siebold \& Zucc.) Endl. 편백 & Tr. & As & PIP (CAP) & \\
\hline 7. Cryptomeria japonica (Thunb. ex L.f.) D.Don 삼나무 & Tr. & As & PIP (CAP) & \\
\hline \multicolumn{5}{|l|}{ Juglandaceae 가래나무과 } \\
\hline 8. Pterocarya stenoptera C. DC. 중국굴피나무 & $\operatorname{Tr}$ & As & IAP (NP) & PS \\
\hline \multicolumn{5}{|l|}{ Salicaceae 버드나무과 } \\
\hline 9. Populus alba L. 은백양 & Tr. & As & PIP (CAP) & \\
\hline 10. Populus nigra L. 양버들 & $\operatorname{Tr}$ & $\mathrm{Eu}$ & PIP (CAP) & \\
\hline 11. Populus $\times$ canadensis Moench 이태리포플라 & Tr. & $\mathrm{nA}$ & PIP (CAP) & \\
\hline 12. Salix babylonica L. 수양버들 & Tr. & As & Arc. & \\
\hline 13. Salix matsudana Koidz. f. tortuosa (Vilm.) Rehder 용버들 & Tr. & As & PIP (CAP) & \\
\hline \multicolumn{5}{|l|}{ Betulaceae 자작나무과 } \\
\hline 14. Alnus firma Siebold \& Zucc. 사방오리 & Tr. & As & PIP (CAP) & \\
\hline 15. Alnus pendula Matsum. 좀사방오리 & Tr. & As & PIP (CAP) & \\
\hline \multicolumn{5}{|l|}{ Moraceae 뽛나무과 } \\
\hline 16. Ficus carica $\mathrm{L}$ 무화과나무 & Pe. & $\mathrm{Eu}, \mathrm{As}$ & PIP (CAP) & \\
\hline 17. Morus alba L. 뽕나무 & Pe. & As & Arc. & \\
\hline \multicolumn{5}{|l|}{ Cannabaceae 삼과 } \\
\hline 18. Cannabis sativa L. 삼 & 1 & As, Eu & Arc. & \\
\hline \multicolumn{5}{|l|}{ Polygonaceae 마디풀과 } \\
\hline 19. Fagopyrum esculentum Moench 메밀 & 1 & As & Arc. & \\
\hline 20. Fagopyrum tataricum (L.) Gaertn. 쓴메밀 & 1 & As & PIP (UN) & \\
\hline 21. Fallopia convolvulus (L.) Á. Löve 나도닭의덩굴 & 1 & Af, As, $\mathrm{Eu}$ & IAP (NP) & PS \\
\hline 22. Persicaria capitata (Buch.-Ham. ex D. Don) H. Gross 메밀여뀌 & Pe. & As & IAP (NP) & PS \\
\hline 23. Persicaria orientalis (L.) Spach 털여뀌 & 1 & As, Oc & IAP (NP) & $\mathrm{CS}$ \\
\hline 24. Persicaria tinctoria (Aiton) Spach 空 & 1 & As & Arc. & \\
\hline 25. Persicaria wallichii Greuter \& Burdet 히 말라야여뀌 & Pe. & Af, As, Eu & PIP (UN) & \\
\hline 26. Polygonum equisetiforme $\mathrm{Sm}$. 개마디풀 & Pe. & $\mathrm{Af}, \mathrm{As}, \mathrm{Eu}$ & PIP (UN) & \\
\hline 27. Polygonum ramosissimum Michx. 미국갯마디풀 & 1 & $\mathrm{nA}$ & IAP (CAP) & PS \\
\hline 28. Reynoutria multiflora (Thunb.) Moldenke 하수오 & Pe. & As & IAP (NP) & MS \\
\hline 29. Rumex acetosella L. 애기수영 & Pe. & As, Eu & IAP (NP) & WS \\
\hline 30. Rumex conglomeratus Murray 묵밭소리쟁이 & Pe. & Af, As, Eu & IAP (NP) & PS \\
\hline
\end{tabular}


Appendix 1. Continued.

\begin{tabular}{|c|c|c|c|c|}
\hline List & L-f & Orig. & Type of alien plant & Degree \\
\hline 31. Rumex crispus L. 소리쟁이 & Pe. & Af, As, Eu & IAP (NP) & WS \\
\hline 32. Rumex dentatus L. 좀소리쟁이 & Pe. & Af, As, Eu & IAP (NP) & PS \\
\hline 33. Rumex obtusifolius L. 돌소리쟁이 & Pe. & Af, As, Eu & IAP (NP) & MS \\
\hline 34. Rumex patientia L. 부령소리쟁이 & Pe. & As, Eu & IAP (NP) & PS \\
\hline 35. Phytolacca acinosa Roxb. 자리공 & Pe. & As, Eu & Arc. & \\
\hline 36. Phytolacca americana L. 미국자리공 & Pe. & $\mathrm{nA}, \mathrm{sA}$ & IAP (NP) & WS \\
\hline \multicolumn{5}{|l|}{ Nyctaginaceae 분꽃과 } \\
\hline 37. Mirabilis jalapa L. 분꽃 & Pe. & sA & IAP (NP) & PS \\
\hline \multicolumn{5}{|l|}{ Molluginaceae 석류풀과 } \\
\hline 38. Mollugo verticillata L. 큰석류풀 & 1 & $\mathrm{nA}, \mathrm{sA}$ & IAP (NP) & PS \\
\hline \multicolumn{5}{|l|}{ Portulacaceae 쇠비름과 } \\
\hline 39. Portulaca grandiflora Hook. 채송화 & Pe. & sA & PIP (UN) & \\
\hline \multicolumn{5}{|l|}{ Caryophyllaceae 석죽과 } \\
\hline 40. Agrostemma githago L. 선옹초 & 1 & $\mathrm{Eu}, \mathrm{As}$ & PIP (UN) & \\
\hline 41. Cerastium glomeratum Thuill. 유럽점나도나물 & 2 & Af, $\mathrm{Eu}$ & IAP (NP) & MS \\
\hline 42. Dianthus armeria L. 유럽패랭이꽃 & 2 & $\mathrm{Eu}, \mathrm{As}$ & IAP (CAP) & PS \\
\hline 43. Dianthus barbatus L. var. asiaticus 수염패랭이꽃 & Pe. & As & PIP (CAP) & \\
\hline 44. Dianthus caryophyllus L. 카네이션 & Pe. & $\mathrm{Eu}$ & PIP (CAP) & \\
\hline 46. Holosteum umbellatum L. 산형나도별꽃 & 1 & Af, As, Eu & IAP (CAP) & PS \\
\hline 47. Psammophiliella muralis (L.) Ikonn. 분홍안개꽃 & 1 & As, $\mathrm{Eu}$ & PIP (CAP) & \\
\hline 48. Saponaria officinalis L. 비누풀 & Pe. & $\mathrm{Eu}$ & IAP (CAP) & PS \\
\hline 49. Scleranthus annuus L. 다북개미자리 & 1 & As, $\mathrm{Eu}$ & IAP (NP) & PS \\
\hline 50. Silene antirrhina L. 가는끈근이장구채 & 1 & $\mathrm{nA}$ & IAP (CAP) & PS \\
\hline 51. Silene armeria L. 끈근이대나물 & 1 & $\mathrm{Eu}$ & IAP (NP) & $\mathrm{CS}$ \\
\hline 52. Silene conoidea L. 염주장구채 & 1 & As, Eu & IAP (CAP) & PS \\
\hline 53. Silene gallica L. 양장구채 & 2 & $\mathrm{Eu}$ & IAP (NP) & PS \\
\hline 54. Silene latifolia Poir. subsp. alba (Mill.) Greuter \& Burdet 달맞이장구채 & 2 & Af, As, Eu & IAP (NP) & PS \\
\hline 55. Silene noctiflora L. 말냉이장구채 & 1 & As, $\mathrm{Eu}$ & IAP (NP) & PS \\
\hline 56. Spergula arvensis L. 들개미자리 & 1 & Af, As, Eu & IAP (NP) & PS \\
\hline 57. Spergularia bocconei (Scheele) Graebn. 끈적털갯개미자리 & 1 & As, $\mathrm{Eu}$ & IAP (CAP) & PS \\
\hline 58. Spergularia rubra (L.) J. Presl \& C.Presl 유럽개미자리 & 1 & Af, As, Eu & IAP (NP) & PS \\
\hline 59. Stellaria media (L.) Vill. 별꽃 & 1 & Af, As, Eu & IAP (NP) & WS \\
\hline 60. Vaccaria hispanica (Mill.) Rauschert 말뱅이나물 & 1 & $\mathrm{As}, \mathrm{Eu}$ & PIP (UN) & \\
\hline \multicolumn{5}{|l|}{ Chenopodiaceae 명아주과 } \\
\hline 61. ATriplex hastata L. 창명아주 & 1 & $\mathrm{Eu}$ & IAP (NP) & PS \\
\hline 62. Bassia scoparia (L.) A. J. Scott 댑싸리 & 1 & As, Eu & IAP (NP) & PS \\
\hline 63. Chenopodium album L. 흰명아주 & 1 & $\mathrm{As}, \mathrm{Eu}$ & IAP (NP) & $\mathrm{CS}$ \\
\hline 64. Chenopodium ficifolium $\mathrm{Sm}$. 좀명아주 & 1 & As, Eu & IAP (NP) & WS \\
\hline 65. Chenopodium glaucum L. 취명아주 & 1 & $\mathrm{As}, \mathrm{Eu}$ & IAP (NP) & SS \\
\hline 66. Chenopodium hybridum L. 얇은명아주 & 1 & As, Eu & PIP (UN) & \\
\hline
\end{tabular}


Appendix 1. Continued.

\begin{tabular}{|c|c|c|c|c|}
\hline List & L-f & Orig. & Type of alien plant & Degree \\
\hline 67. Chenopodium pumilio $\mathrm{R}$. Br. 냄새명아주 & 1 & Oc & IAP (NP) & PS \\
\hline 68. Dysphania ambrosioides (L.) Mosyakin \& Clemants 양명아주 & 1 & $\mathrm{nA}, \mathrm{sA}, \mathrm{Oc}$ & IAP (NP) & MS \\
\hline \multicolumn{5}{|l|}{ Amaranthaceae 비름과 } \\
\hline 69. Alternanthera sessilis (L.) R. Br. ex DC. 덩굴맨드라미 & Pe. & As, sA, Oc & PIP (CAP) & \\
\hline 70. Amaranthus albus L. 미국비름 & 1 & $\mathrm{nA}$ & PIP (UN) & \\
\hline 71. Amaranthus arenicola I. M. Johnst. 각시비름 & 1 & $\mathrm{nA}$ & PIP (UN) & \\
\hline 72. Amaranthus blitum L. subsp. oleraceus (L.) Costea 개비름 & 1 & $\mathrm{Eu}$ & Arc. & \\
\hline 73. Amaranthus caudatus L. 줄맨드라미 & Pe. & sA & IAP (NP) & PS \\
\hline 74. Amaranthus deflexus L. 눈비름 & Pe. & sA & $\mathrm{IAP}(\mathrm{CAP})$ & PS \\
\hline 75. Amaranthus hybridus L. 긴털비름 & 1 & $\mathrm{nA}, \mathrm{sA}$ & IAP (NP) & PS \\
\hline 76. Amaranthus palmeri S. Watson 긴이삭비름 & 1 & $\mathrm{nA}$ & PIP (UN) & \\
\hline 77. Amaranthus patulus Bertol. 가는털비름 & 1 & $\mathrm{nA}, \mathrm{sA}$ & IAP (NP) & $\mathrm{CS}$ \\
\hline 78. Amaranthus powellii S. Watson 민털비름 & 1 & $\mathrm{nA}$ & IAP (CAP) & PS \\
\hline 79. Amaranthus reTroflexus L. 털비름 & 1 & $\mathrm{nA}$ & PIP (UN) & \\
\hline 80. Amaranthus spinosus L. 가시비름 & 1 & $\mathrm{nA}, \mathrm{sA}$ & IAP (NP) & PS \\
\hline 81. Amaranthus tricolor L. 비름 & 1 & As & PIP (UN) & \\
\hline 82. Amaranthus viridis L. 청비름 & 1 & $\mathrm{nA}, \mathrm{sA}$ & IAP (NP) & PS \\
\hline 83. Celosia argentea L. 개맨드라미 & 1 & Af & IAP (NP) & MS \\
\hline 84. Gomphrena globosa L. 천일홍 & 1 & sA & PIP (CAP) & \\
\hline \multicolumn{5}{|l|}{ Cactaceae 선인장과 } \\
\hline 85. Opuntia ficus-indica (L.) Mill. 보검선인장 & Pe. & $\mathrm{nA}$ & PIP (CAP) & \\
\hline 86. Opuntia humifusa (Raf.) Raf. 후미푸사선인장 & Pe. & $\mathrm{nA}$ & PIP (CAP) & \\
\hline 87. Opuntia monacantha (Willd.) Haw. 왕선인장 & Pe. & sA & PIP (CAP) & \\
\hline \multicolumn{5}{|l|}{ Magnoliaceae 목련과 } \\
\hline 88. Liriodendron tulipifera L. 백합나무 & Pe. & $\mathrm{nA}$ & PIP (CAP) & \\
\hline 89. Magnolia obovata Thunb. 일본목련 & Tr. & As & IAP (NP) & PS \\
\hline \multicolumn{5}{|l|}{ Cercidiphyllaceae 계수나무과 } \\
\hline 90. Cercidiphyllum japonicum Siebold \& Zucc. ex J. J. Hoffm. \& J. H. Schult .bis 계수나무 & Tr. & As & PIP (CAP) & \\
\hline \multicolumn{5}{|l|}{ Ranunculaceae 미나리아재비과 } \\
\hline 91. Delphinium ajacis L. 참제비고깔 & 2 & As, Eu & PIP (UN) & \\
\hline 92. Ranunculus arvensis L. 좀미나리아재비 & 1 & Af, As, Eu & PIP (UN) & \\
\hline 93. Ranunculus muricatus L. 유럽미나리아재비 & 1 & As, Eu & IAP (NP) & PS \\
\hline 94. Ranunculus sardous Crantz 털개구리자리 & 2 & Af, Eu & $\mathrm{IAP}(\mathrm{CAP})$ & PS \\
\hline \multicolumn{5}{|l|}{ Berberidaceae 매자나무과 } \\
\hline 95. Mahonia japonica (Thunb.) DC. 뿔남천 & Tr. & As & IAP (CAP) & PS \\
\hline \multicolumn{5}{|l|}{ Nymphaeaceae 수련과 } \\
\hline 96. Nymphaea alba L. 유럽수련 & Pe. & Af, As, Eu & PIP (CAP) & \\
\hline 97. Nymphaea odorata Aiton 미국수련 & Pe. & $\mathrm{nA}, \mathrm{sA}$ & PIP (CAP) & \\
\hline \multicolumn{5}{|l|}{ Nelumbonaceae 연과 } \\
\hline 98. Nelumbo nucifera Gaertn. 연 ᄁᄁㅗㅊ & Pe. & As, Eu & PIP (CAP) & \\
\hline
\end{tabular}


Appendix 1. Continued.

List

\section{Cabombaceae 어항마름과}

99. Cabomba caroliniana A. Gray 어항마름

\section{Saururaceae 삼백초과}

100. Houttuynia cordata Thunb. 약모밀

\section{Actinidiaceae 다래나무과}

101. Actinidia chinensis Planch. var. deliciosa A. Chev.) A.Chev 양다래

\section{Theaceae 차나무과}

102. Camellia sinensis (L.) Kuntze 차나무

\section{Clusiaceae 물레나물과}

103. Hypericum perforatum L. 서양고추나물

\section{Papaveraceae 양귀비과}

104. Eschscholzia californica Cham. 금영화

105. Fumaria officinalis L. 둥근빗살괴불주머니

106. Papaver dubium L. 좀양귀비

107. Papaver hybridum L. 바늘양귀비

108. Papaver rhoeas L. 개양귀비

109. Papaver somniferum L. subsp. setigerum (DC.) Arcang. 나도양귀비

\section{Brassicaceae 십자화과}

110. Alliaria petiolata (M. Bieb.) Cavara \& Grande 마늘냉이

111. Armoracia rusticana G. Gaertn., B. Mey. \& Schreb. 겨자무

112. Barbarea verna (Mill.) Asch. 봄나도냉이

113. Barbarea vulgaris R. Br. 유럽나도냉이

114. Brassica juncea (L.) Czern. 갓

115. Brassica napus L. 유채

116. Cakile edentula (Bigelow) Hook. 서양갯냉이

117. Camelina microcarpa Andrz. ex DC. 좀아마냉이

118. Camelina sativa (L.) Crantz 양구슬냉이

119. Chorispora tenella DC. 뿔냉이

120. Conringia orientalis (L.) C. Presl 토끼귀부지깽이

121. Coronopus didymus (L.) Sm. 냄새냉이

122. Descurainia pinnata Britton 나도재쑥

123. Descurainia sophia (L.) Webb ex Prantl 재쑥

124. Diplotaxis muralis DC. 모래냉이

125. Erucastrum gallicum O. E. Schulz 큰잎냉이

126. Erysimum cheiranthoides L. 쑥부지깽이

127. Iberis amara L. 서양말냉이

128. Lepidium apetalum Willd. 다닥냉이

129. Lepidium bonariense L. 국화잎다닥냉이

130. Lepidium campestre (L.) W. T. Aiton 들다닥냉이

131. Lepidium densiflorum Schrad. 길다닥냉이

L-f

Orig.

Type of alien plant Degree

Pe.

$\mathrm{nA}, \mathrm{sA}$

IAP (CAP)

PS

Pe.

As

Arc.

Pe.

As

PIP (CAP)

Pe.

As

PIP (CAP)

Pe

Af, As, Eu

IAP (NP)

PS

Pe.

$\mathrm{nA}, \mathrm{sA}$

IAP (CAP) PS

$\mathrm{Eu}$

IAP (NP)

PS

Af, As, Eu

IAP (NP)

PS

As, Eu

PIP (UN)

Af, As, Eu

$\mathrm{Eu}$

IAP (NP)

PS

PIP (UN)

2

Pe.

Af, As, Eu

IAP (CAP)

PS

As, Eu

IAP (CAP) PS

Eu

Pe. As, Eu

2

As

$\mathrm{Eu}$

$\mathrm{nA}$

Af, As, Eu

As, Eu

As, Eu

As, Eu

sA

nA

As, Eu

Af, As, Eu

Eu

As, Eu

$\mathrm{Eu}$

As, Eu

sA

As, Eu

$\mathrm{nA}, \mathrm{sA}$
IAP (CAP) PS

IAP (NP) MS

Arc.

Arc.

IAP (NP) PS

IAP (NP) PS

IAP (NP) PS

IAP (NP) PS

PIP (UN)

IAP (NP) PS

PIP (UN)

IAP (NP) MS

IAP (NP) PS

PIP (UN)

IAP (CAP) PS

PIP (CAP)

PIP (UN)

IAP (NP) PS

PIP (UN)
IAP (NP) PS 
Appendix 1. Continued.

\begin{tabular}{|c|c|c|c|c|}
\hline List & L-f & Orig. & Type of alien plant & Degree \\
\hline 132. Lepidium draba L. 큰잎다닥냉이 & Pe. & Af, As, Eu & IAP (NP) & PS \\
\hline 133. Lepidium latifolium L. 큰키다닥냉이 & Pe. & Af, As, Eu & PIP (UN) & \\
\hline 134. Lepidium perfoliatum $\mathrm{L}$. 대부도냉이 & 2 & As, Eu & IAP (NP) & PS \\
\hline 135. Lepidium pinnatifidum Ledeb. 털다닥냉이 & Pe. & As, Eu & IAP (CAP) & PS \\
\hline 136. Lepidium ruderale L. 좀다닥냉이 & 2 & As, Eu & PIP (UN) & \\
\hline 137. Lepidium sativum L. 큰다닥냉이 & 1 & As, Eu & PIP (UN) & \\
\hline 138. Lepidium virginicum $\mathrm{L}$. 콩다닥냉이 & 2 & $\mathrm{nA}$ & IAP (NP) & SS \\
\hline 139. Myagrum perfoliatum L. 장수냉이 & 1 & As, Eu & PIP (UN) & \\
\hline 140. Nasturtium officinale R.Br. 물냉이 & Pe. & Af, As, Eu & IAP (NP) & PS \\
\hline 141. Neslia paniculata (L.) Desv. 구슬다닥냉이 & 2 & As, Eu & PIP (UN) & \\
\hline 142. Orychophragmus violaceus (L.) O. E. Schulz 소래풀 & 2 & As & PIP (CAP) & \\
\hline 143. Raphanus raphanistrum L. 서양무아재비 & 2 & As, Eu & PIP (UN) & \\
\hline 144. Rapistrum rugosum (L.) All. 주름구슬냉이 & 1 & Af, As, Eu & PIP (UN) & \\
\hline 145. Rorippa sylvestris (L.) Besser 가새잎개갓냉이 & Pe. & As, Eu & IAP (NP) & PS \\
\hline 146. Sinapis arvensis L. 들갓 & 1 & Af, As, Eu & IAP (NP) & PS \\
\hline 147. Sisymbrium altissimum L. 가는잎털냉이 & 1 & As, Eu & IAP (NP) & PS \\
\hline 148. Sisymbrium irio L. 깃털장대 & 1 & Af, As, Eu & IAP (CAP) & PS \\
\hline 149. Sisymbrium officinale (L.) Scop. 유럽장대 & 1 & Af, As, Eu & IAP (NP) & PS \\
\hline 150. Sisymbrium orientale L. 긴갓냉이 & 1 & As, Eu & IAP (NP) & PS \\
\hline 151. Thlaspi arvense L. 말냉이 & 2 & As, Eu & Arc. & \\
\hline \multicolumn{5}{|l|}{ Platanaceae 버즘나무과 } \\
\hline 152. Platanus occidentalis L. 양버즘나무 & Tr. & $\mathrm{nA}$ & PIP (CAP) & \\
\hline \multicolumn{5}{|l|}{ Crassulaceae 돌나물과 } \\
\hline 153. Sedum makinoi Maxim. 둥근잎비름 & 1 & As & PIP (CAP) & \\
\hline 154. Sedum mexicanum Britton 멕시코돌나물 & Pe. & sA & IAP (NP) & PS \\
\hline \multicolumn{5}{|l|}{ Saxifragaceae 범의귀과 } \\
\hline 155. Bergenia stracheyi (Hook.f. \& Thomson) Engl. 히말라야바위취 & Pe. & As & PIP (CAP) & \\
\hline \multicolumn{5}{|l|}{ Hydrangeaceae 수국과 } \\
\hline 156. Hydrangea macrophylla (Thunb.) Ser. 수국 & Pe. & As & PIP (CAP) & \\
\hline \multicolumn{5}{|l|}{ Rosaceae 장미과 } \\
\hline 157. Chaenomeles japonica (Thunb.) Lindl. ex Spach 풀명자 & Pe. & As & PIP (CAP) & \\
\hline 158. Chaenomeles lagenaria (Loisel.) Koidz. 명자나무 & Pe. & As & PIP (CAP) & \\
\hline 159. Kerria japonica (L.) DC. 황매화 & Pe. & As & PIP (CAP) & \\
\hline 160. Potentilla supina L. 개소시 랑개비 & 2 & Af, As, Eu & IAP (NP) & SS \\
\hline 161. Prunus persica (L.) Batsch 복사나무 & Tr. & As & Arc. & \\
\hline 162. Prunus speciosa (Koidz.) Nakai 왜벚나무 & Tr. & As & PIP (CAP) & \\
\hline 163. Prunus tomentosa Thunb. 앵도나무 & Tr. & As & PIP (CAP) & \\
\hline 164. Rosa multiflora Thunb. var. platyphylla Thory 덩굴장미 & Pe. & As & PIP (CAP) & \\
\hline 165. Rubus fruticosus L. 서양오엽 딸기 & Tr. & $\mathrm{Eu}$ & IAP (NP) & PS \\
\hline 166. Sanguisorba minor Scop. 술오이풀 & Pe. & $\mathrm{Af}, \mathrm{As}, \mathrm{Eu}$ & PIP (UN) & \\
\hline
\end{tabular}


Appendix 1. Continued.

\begin{tabular}{|c|c|c|c|c|}
\hline List & L-f & Orig. & Type of alien plant & Degree \\
\hline 167. Spiraea cantoniensis Lour. 공조팝나무 & Pe. & As & PIP (CAP) & \\
\hline 168. Spiraea thunbergii Siebold ex Blume 가는잎조팝나무 & Pe. & As & PIP (CAP) & \\
\hline \multicolumn{5}{|l|}{ Fabaceae 콩과 } \\
\hline 169. Amorpha canescens Pursh 털족제비싸리 & Tr. & $\mathrm{nA}$ & PIP (CAP) & \\
\hline 170. Amorpha fruticosa L. 족제비싸리 & Tr. & $\mathrm{nA}$ & IAP (NP) & WS \\
\hline 171. Astragalus sinicus L. 자운영 & 2 & As & IAP (NP) & SS \\
\hline 172. Caragana sinica (Buc'hoz) Rehder 골담초 & Pe. & As & PIP (CAP) & \\
\hline 173. Cercis chinensis Bunge 박태기나무 & Pe. & As & PIP (CAP) & \\
\hline 174. Cytisus scoparius (L.) Link 양골담초 & Pe. & $\mathrm{Eu}$ & PIP (CAP) & \\
\hline 175. Galega officinalis L. 오피키날리스갈레가 & Pe. & $\mathrm{Eu}$ & PIP (CAP) & \\
\hline 176. Indigofera bungeana Walp. 큰낭아초 & Tr. & As & IAP (CAP) & PS \\
\hline 177. Lathyrus aphaca L. 쌍부채완두 & 1 & As, Eu & PIP (UN) & \\
\hline 178. Lespedeza davidii Franch. 큰잎싸리 & $\operatorname{Tr}$ & As & PIP (UN) & \\
\hline 179. Lespedeza floribunda Bunge 분홍싸리 & Tr. & As & PIP (UN) & \\
\hline 180. Lespedeza lichiyuniae T. Nemoto \& H. Ohashi \& T. Itô 자주비수리 & Tr. & As & IAP (NP) & PS \\
\hline 181. Lotus corniculatus L. 서양벌노랑이 & Pe. & Af, As, Eu & IAP (NP) & PS \\
\hline 182. Lotus pedunculatus Cav. 들벌노랑이 & Pe. & $\mathrm{Af}, \mathrm{Eu}$ & IAP (NP) & PS \\
\hline 183. Lotus tenuis Waldst. \& Kit. ex Willd. 좁은잎벌노랑이 & Pe. & Af, Eu & PIP (UN) & \\
\hline 184. Lupinus angustifolius L. 가는잎미선콩 & 1 & $\mathrm{Eu}$ & PIP (UN) & \\
\hline 185. Medicago lupulina L. 잔개자리 & 2 & Af, As, Eu & IAP (NP) & MS \\
\hline 186. Medicago minima (L.) Bartal. 좀개자리 & 1 & Af, As, Eu & IAP (NP) & PS \\
\hline 187. Medicago polymorpha L. 개자리 & 1 & Af, As, Eu & IAP (NP) & MS \\
\hline 188. Medicago sativa L. 자주개자리 & Pe. & $\mathrm{Eu}$ & IAP (NP) & $\mathrm{CS}$ \\
\hline 189. Melilotus albus Medik. 흰전동싸리 & 2 & Af, As, Eu & IAP (NP) & MS \\
\hline 190. Melilotus indicus (L.) All. 좀전동싸리 & 1 & Af, As, Eu & IAP (CAP) & PS \\
\hline 191. Melilotus officinalis (L.) Lam. 주름전동싸리 & 2 & $\mathrm{As}, \mathrm{Eu}$ & IAP (CAP) & PS \\
\hline 192. Melilotus suaveolens Ledeb. 전동싸리 & 2 & As & IAP (NP) & $\mathrm{CS}$ \\
\hline 193. Mimosa pudica L. 미모사 & Pe. & sA & PIP (CAP) & \\
\hline 194. Robinia pseudoacacia L. 아까시나무 & Tr. & $\mathrm{nA}$ & IAP (NP) & WS \\
\hline 195. Securigera varia (L.) Lassen 왕관갈퀴나물 & 1 & $\mathrm{As}, \mathrm{Eu}$ & $\mathrm{IAP}(\mathrm{CAP})$ & PS \\
\hline 196. Senna occidentalis (L.) Link 석결명 & 1 & $\mathrm{nA}, \mathrm{sA}$ & PIP (CAP) & \\
\hline 197. Senna tora (L.) Roxb. 결명자 & 1 & $\mathrm{nA}, \mathrm{sA}$ & Arc. & \\
\hline 198. Styphnolobium japonicum (L.) Schott 회화나무 & Pe. & As & PIP (CAP) & \\
\hline 199. Trifolium campestre Schreb. 노랑토끼풀 & 1 & Af, As, Eu & IAP (NP) & PS \\
\hline 200. Trifolium dubium Sibth. 애기노랑토끼풀 & Pe. & $\mathrm{Eu}$ & IAP (NP) & PS \\
\hline 201. Trifolium hybridum L. 선토끼풀 & Pe. & $\mathrm{As}, \mathrm{Eu}$ & IAP (NP) & PS \\
\hline 202. Trifolium incarnatum L. 진홍토끼풀 & 1 & As, Eu & IAP (CAP) & PS \\
\hline 203. Trifolium pratense L. 붉은토끼풀 & Pe. & Af, As, Eu & IAP (NP) & SS \\
\hline 204. Trifolium repens L. 토끼풀 & Pe. & Af & IAP (NP) & WS \\
\hline 205. Trifolium resupinatum L. 거꿀꽃토끼풀 & 1 & As, Eu & IAP (CAP) & PS \\
\hline
\end{tabular}


Appendix 1. Continued.

\begin{tabular}{|c|c|c|c|c|}
\hline List & $\begin{array}{c}\text { L-f } \\
\end{array}$ & Orig. & Type of alien plant & Degree \\
\hline 206. Ulex europaeus L. 울렉스 & Tr. & Af, As, Eu & PIP (CAP) & \\
\hline 207. Vicia dasycarpa Ten. 각시갈퀴나물 & 2 & As, Eu & IAP (NP) & PS \\
\hline 208. Vicia sepium L. 구주갈퀴덩굴 & Pe. & Af, As, Eu & IAP (CAP) & PS \\
\hline 209. Vicia villosa Roth 벳지 & 2 & Af, As, Eu & IAP (NP) & MS \\
\hline 210. Wisteria floribunda (Willd.) DC. 등 & Pe. & As & Arc. & \\
\hline \multicolumn{5}{|l|}{ Oxalidaceae 갱이밥과 } \\
\hline 211. Oxalis articulata Savigny 덩이괭이밥 & Pe. & sA & IAP (NP) & PS \\
\hline 212. Oxalis bowiei W.T.Aiton ex G. Don 꽃괭이밥 & Pe. & sA & PIP (CAP) & \\
\hline 213. Oxalis corniculata L. 괭이밥 & Pe. & $\mathrm{nA}$ & Arc. & \\
\hline 214. Oxalis debilis Kunth var. corymbosa (DC.) Lourteig 자주괭이밥 & Pe. & sA & IAP (NP) & PS \\
\hline 215. Oxalis dillenii Jacq. 들괭이밥 & Pe. & $\mathrm{nA}, \mathrm{sA}$ & $\mathrm{IAP}(\mathrm{CAP})$ & PS \\
\hline \multicolumn{5}{|l|}{ Geraniaceae 쥐손이풀과 } \\
\hline 216. Erodium cicutarium (L.) L'Hér. 세열유럽쥐손이 & 2 & Af, As, Eu & IAP (NP) & PS \\
\hline 217. Geranium carolinianum L. 미국쥐손이 & 1 & $\mathrm{nA}$ & IAP (NP) & PS \\
\hline 218. Geranium dissectum L. 세열미국쥐손이 & 1 & Af, As, Eu & IAP (CAP) & PS \\
\hline 219. Geranium robertianum L. 연자주쥐손이 & Pe. & Af, As, Eu & $\mathrm{IAP}(\mathrm{CAP})$ & PS \\
\hline \multicolumn{5}{|l|}{ Linaceae 아마과 } \\
\hline 220. Linum usitatissimum L. 아마 & 1 & As & PIP (CAP) & \\
\hline 221. Linum virginianum L. 노랑개아마 & Pe. & $\mathrm{nA}$ & IAP (NP) & PS \\
\hline \multicolumn{5}{|l|}{ Euphorbiaceae 대극과 } \\
\hline 222. Euphorbia dentata Michx. 톱니대극 & 1 & $\mathrm{nA}$ & IAP (CAP) & PS \\
\hline 223. Euphorbia heterophylla L. 아메리카대극 & 1 & $\mathrm{nA}$ & IAP (CAP) & PS \\
\hline 224. Euphorbia hirta L. 털땅빈대 & 1 & $\mathrm{nA}$ & IAP (CAP) & PS \\
\hline 225. Euphorbia hypericifolia L. 큰땅빈대 & 1 & $\mathrm{nA}, \mathrm{sA}$ & IAP (NP) & $\mathrm{CS}$ \\
\hline 226. Euphorbia marginata Pursh 설악초 & 1 & $\mathrm{nA}$ & PIP (CAP) & \\
\hline 227. Euphorbia prostrata Aiton 누운땅빈대 & 1 & $\mathrm{nA}, \mathrm{sA}$ & IAP (CAP) & PS \\
\hline 228. Euphorbia maculata L. 애기 땅빈대 & 1 & $\mathrm{nA}, \mathrm{sA}$ & IAP (NP) & SS \\
\hline 229. Euphorbia makinoi Hayata 뿌리땅빈대 & 1 & As & IAP (CAP) & PS \\
\hline 230. Ricinus communis L. 피마자 & 1 & Af & PIP (CAP) & \\
\hline 231. Vernicia fordii (Hemsl.) Airy Shaw 유동 & $\operatorname{Tr}$ & As & PIP (CAP) & \\
\hline \multicolumn{5}{|l|}{ Simaroubaceae 소태나무과 } \\
\hline 232. Ailanthus altissima (Mill.) Swingle 가죽나무 & $\operatorname{Tr}$. & As & Arc. & \\
\hline \multicolumn{5}{|l|}{ Meliaceae 멀구슬나무과 } \\
\hline 233. Melia azedarach L. 멀구슬나무 & Tr. & As, Oc & Arc. & \\
\hline 234. Toona sinensis (Juss.) M. Roem. 참죽나무 & Tr. & As & Arc. & \\
\hline \multicolumn{5}{|l|}{ Anacardiaceae 옻나무과 } \\
\hline 235. Toxicodendron vernicifluum (Stokes) F. A. Barkley 옻나무 & Pe. & As & Arc. & \\
\hline \multicolumn{5}{|l|}{ Aceraceae 단풍나무과 } \\
\hline 236. Acer buergerianum Miq. 중국단풍 & Tr. & As & PIP (CAP) & \\
\hline 237. Acer saccharinum L. 은단풍 & Pe. & $\mathrm{nA}$ & PIP (CAP) & \\
\hline
\end{tabular}


Appendix 1. Continued.

List

\section{Hippocastanaceae 칠엽수과}

238. Aesculus turbinata Blume 칠엽수

\section{Balsaminaceae 봉선화과}

239. Impatiens balsamina L. 봉선화

Aquifoliaceae 감탕나무과

240. Ilex serrata Thunb. 낙상홍

241. Ilex verticillata (L.) A. Gray 미국낙상홍

\section{Vitaceae 포도과}

242. Parthenocissus quinquefolia (L.) Planch. 미국담쟁이덩굴

\section{Malvaceae 아욱과}

243. Abutilon theophrasti Medik. 어저귀

244. Alcea rosea L. 접시꽃

245. Anoda cristata (L.) Schltdl. 나도어저귀

246. Corchorus capsularis L. 황마

247. Hibiscus mutabilis L. 부용

248. Hibiscus syriacus L. 무궁화

249. Hibiscus trionum L. 수박풀

250. Malva neglecta Wallr. 난쟁이아욱

251. Malva parviflora L. 애기아욱

252. Malva pusilla $\mathrm{Sm}$. 둥근잎아욱

253. Malva sylvestris L. 당아욱

254. Malva verticillata L. 아욱

255. Melochia corchorifolia L. 불암초

256. Modiola caroliniana (L.) G. Don 국화잎아욱

257. Sida rhombifolia L. 나도공단풀

258. Sida spinosa L. 공단풀

\section{Sterculiaceae 벽오동과}

259. Firmiana simplex (L.) W. Wight 벽오동나무

Thymelaeaceae 팥쫓나무과

260. Edgeworthia chrysantha Lindl. 삼지닥나무

Elaeagnaceae 보리수나무과

261. Elaeagnus pungens Thunb. 통영볼레나무

Violaceae 제비꽃과

262. Viola arvensis Murray 야생 팬지

263. Viola papilionacea Pursh 종지나물

\section{Tamaricaceae 위성류과}

264. Tamarix chinensis Lour. 위성류

Cucurbitaceae 박과

265. Citrullus lanatus (Thunb.) Matsum. \& Nakai 수박

266. Cucumis melo L. 참외

L-f

Orig.

Type of alien plant Degree

Tr.

As

PIP (CAP)

1

As

PIP (CAP)

$\begin{array}{llll}\text { Tr. } & \text { As } & \text { IAP (CAP) } & \text { PS } \\ \text { Tr. } & \text { nA } & \text { PIP (CAP) } & \end{array}$

Pe.

$\mathrm{nA}, \mathrm{sA}$

PIP (CAP)

Pe.

1

$\mathrm{Pe}$

Pe.

Pe.

1

2

1$$
1
$$$$
2
$$

2

As, Eu PIP (UN)

nA, sA PIP (CAP)

As PIP (CAP)

As PIP (CAP)

As PIP (CAP)

$\mathrm{Eu} \quad \mathrm{IAP}(\mathrm{NP}) \quad \mathrm{MS}$

Eu, Af IAP (NP) PS

As, Eu $\mathrm{EAP}(\mathrm{NP}) \quad$ PS

As, Eu IAP (NP) PS

$\mathrm{As}, \mathrm{Eu} \quad \mathrm{IAP}(\mathrm{NP}) \quad$ PS

As, Af PIP (UN)

Af, Oc, As IAP (CAP) PS

SA IAP (NP) PS

sA, As IAP (NP) PS

Af, sA, As IAP (NP) PS

As. Arc.

Tr. As $\quad$ PIP (CAP)

$\begin{array}{lll}\text { Tr. } & \text { As }\end{array}$

$\begin{array}{cccc}1 & \text { As, Eu } & \text { IAP (NP) } & \text { PS } \\ \text { Pe. } & \text { nA } & \text { IAP (NP) } & \text { PS }\end{array}$

Tr. As $\quad$ PIP (CAP)

$1 \quad$ Af $\quad$ PIP (CAP)

$1 \quad$ Af, Oc, As $\quad$ PIP (CAP) 
Appendix 1. Continued.

\begin{tabular}{|c|c|c|c|c|}
\hline List & L-f & Orig. & Type of alien plant & Degree \\
\hline 267. Sicyos angulatus L. 가시박 & 1 & $\mathrm{nA}, \mathrm{Oc}$ & IAP (NP) & MS \\
\hline \multicolumn{5}{|l|}{ Lythraceae 부처꽃과 } \\
\hline 268. Ammannia coccinea Rottb. 미국좀부처꽃 & 1 & $\mathrm{nA}, \mathrm{sA}$ & IAP (NP) & PS \\
\hline 269. Lagerstroemia indica L. 배롱나무 & Pe. & As & Arc. & \\
\hline \multicolumn{5}{|l|}{ Onagraceae 바늘꽃과 } \\
\hline 270. Gaura lindheimeri Engelm. \& A. Gray 가우라 & Pe. & sA & PIP (CAP) & \\
\hline 271. Ludwigiapeploides(Kunth)P.H.Ravensubsp. montevidensis(Spreng)P.H.Raven 꽃여 뀌 바늘 & Pe. & sA & PIP (CAP) & \\
\hline 272. Oenothera biennis L. 달맞이꽃 & 2 & $\mathrm{nA}$ & IAP (NP) & WS \\
\hline 273. Oenothera glazioviana Micheli 큰달맞이꽃 & 2 & sA & IAP (NP) & PS \\
\hline 274. Oenothera laciniata Hill 애기달맞이꽃 & 2 & $\mathrm{nA}, \mathrm{sA}$ & IAP (NP) & PS \\
\hline 275. Oenothera macrocarpa Nutt. 왕달맞이꽃 & Pe. & $\mathrm{nA}$ & $\mathrm{IAP}(\mathrm{CAP})$ & PS \\
\hline 276. Oenothera rosea L'Her. ex Aiton 애기분홍낮달맞이꽃 & Pe. & $\mathrm{nA}, \mathrm{sA}$ & IAP (CAP) & PS \\
\hline 277. Oenothera speciosa Nutt 분홍낮달맞이꽃 & Pe. & $\mathrm{nA}$ & PIP (CAP) & \\
\hline 278. Oenothera stricta Ledeb. ex Link 긴잎달맞이꽃 & 2 & sA & IAP (NP) & PS \\
\hline \multicolumn{5}{|l|}{ Haloragaceae 개미탑과 } \\
\hline 279. Myriophyllum aquaticum (Vell.) Verdc. 앵무새깃물수세미 & Pe. & sA & PIP (CAP) & \\
\hline \multicolumn{5}{|l|}{ Araliaceae 두릅나무과 } \\
\hline 280. Tetrapanax papyrifer (Hook.) K. Koch 통달목 & Tr. & As & PIP (CAP) & \\
\hline \multicolumn{5}{|l|}{ Apiaceae 산형과 } \\
\hline 281. Anthriscus caucalis M. Bieb. 유럽전호 & 1 & Af, Eu & IAP (NP) & PS \\
\hline 282. Apium graveolens L. 샐러리 & 2 & Af, As, Eu & PIP (CAP) & \\
\hline 283. Apium leptophyllum (Pers.) F. Muell. ex Benth. 솔잎미나리 & 1 & sA & IAP (NP) & PS \\
\hline 284. Bifora radians M. Bieb. 쌍구슬풀 & 1 & As, Eu & PIP (UN) & \\
\hline 285. Bowlesia incana Ruiz \& Pav. 병풀아재비 & 1 & $\mathrm{nA}, \mathrm{sA}$ & IAP (CAP) & PS \\
\hline 286. Bupleurum lancifolium Hornem. 쟁 반시호 & 1 & sA, Af, As & PIP (UN) & \\
\hline 287. Chaerophyllum tainturieri Hook. \& Arn. 전호아재비 & 1 & $\mathrm{nA}$ & IAP (CAP) & PS \\
\hline 288. Conium maculatum L. 나도독미나리 & 2 & Af, As, Eu & IAP (NP) & PS \\
\hline 289. Coriandrum sativum L. 고수 & 1 & As, Eu & PIP (CAP) & \\
\hline 290. Daucus carota L. 산당근 & Pe. & As, Eu & IAP (NP) & PS \\
\hline 291. Foeniculum vulgare Mill. 회향 & Pe. & $\mathrm{Af}, \mathrm{Eu}$ & IAP (NP) & PS \\
\hline 292. Lisaea heterocarpa (DC.) Boiss. 이란미나리 & 1 & As & PIP (UN) & \\
\hline 293. Petroselinum crispum (Mill.) Fuss 파슬리 & 1 & $\mathrm{Eu}$ & PIP (CAP) & \\
\hline 294. Scandix pecten-veneris L. 바늘풀 & 1 & As, Eu & PIP (UN) & \\
\hline \multicolumn{5}{|l|}{ Ebenaceae 감나무과 } \\
\hline 295. Diospyros kaki L.f. 감나무 & $\operatorname{Tr}$ & As & PIP (CAP) & \\
\hline \multicolumn{5}{|l|}{ Oleaceae 물푸레나무과 } \\
\hline 296. Osmanthus heterophyllus (G. Don) P. S. Green 구골나무 & Tr. & As & PIP (CAP) & \\
\hline 297. Osmanthus × fortunei Carrière 구골나무목서 & $\operatorname{Tr}$ & As & PIP (CAP) & \\
\hline 298. Syringa vulgaris L. 서양수수꽃다리 & Pe. & $\mathrm{Eu}$ & PIP (CAP) & \\
\hline Loganiaceae 마전과 & & & & \\
\hline
\end{tabular}


Appendix 1. Continued.

\begin{tabular}{|c|c|c|c|c|}
\hline List & L-f & Orig. & Type of alien plant & Degree \\
\hline 299. Buddleja davidi Franch. 부들레야 & Pe. & As & IAP (CAP) & PS \\
\hline \multicolumn{5}{|l|}{ Apocynaceae 협죽도과 } \\
\hline 300. Apocynum cannabinum L. 수궁초 & Pe. & $\mathrm{nA}$ & IAP (CAP) & \multirow[t]{3}{*}{ PS } \\
\hline 301. Nerium oleander L. 협죽도 & Pe. & $\mathrm{Eu}$ & PIP (CAP) & \\
\hline 302. Vinca minor L. 빈카 & Pe. & $\mathrm{Eu}$ & PIP (CAP) & \\
\hline \multicolumn{5}{|l|}{ Rubiaceae 꼭두서니과 } \\
\hline 303. Diodia teres Walter 백령풀 & 1 & $\mathrm{nA}, \mathrm{sA}$ & IAP (NP) & PS \\
\hline 304. Diodia virginiana L. 큰백령풀 & 1 & $\mathrm{nA}, \mathrm{sA}$ & IAP (NP) & PS \\
\hline 305. Galium aparine L. 나도갈퀴덩굴 & 1 & Af, As, Eu & IAP (CAP) & PS \\
\hline 306. Galium tricornutum Dandy 민둥갈퀴덩굴 & 1 & As, Eu & PIP (UN) & \\
\hline 307. Oldenlandia corymbosa L. 산방백 운풀 & Pe. & As, Af & $\mathrm{IAP}(\mathrm{CAP})$ & PS \\
\hline 308. Sherardia arvensis L. 꽃갈퀴덩굴 & 2 & As, Eu & IAP (NP) & PS \\
\hline \multicolumn{5}{|l|}{ Polemoniaceae 꽃고비과 } \\
\hline 309. Phlox drummondii Hook. 드람불꽃 & Pe. & $\mathrm{nA}$ & PIP (CAP) & \\
\hline \multicolumn{5}{|l|}{ Convolvulaceae 메꽃과 } \\
\hline 310. Convolvulus arvensis L. 서양메꽃 & Pe. & Af, As, Eu & IAP (NP) & PS \\
\hline 311. Cuscuta pentagona Engelm. 미국실새삼 & 1 & $\mathrm{nA}, \mathrm{sA}$ & IAP (NP) & $\mathrm{CS}$ \\
\hline 312. Ipomoea lacunosa L. 애기나팔꽃 & 1 & $\mathrm{nA}$ & IAP (NP) & PS \\
\hline 313. Ipomoea muricata (L.) Jacq. 밤메꽃 & Pe. & $\mathrm{nA}$ & IAP (CAP) & PS \\
\hline 314. Ipomoea nil (L.) Roth 나팔꽃 & 1 & sA & IAP (NP) & MS \\
\hline 315. Ipomoea purpurea (L.) Roth 둥근잎나팔꽃 & 1 & $\mathrm{nA}, \mathrm{sA}$ & IAP (NP) & $\mathrm{CS}$ \\
\hline 316. Ipomoea triloba L. 별나팔꽃 & 1 & sA & IAP (NP) & PS \\
\hline 317. Jacquemontia tamnifolia (L.) Griseb. 선나팔꽃 & 1 & $\mathrm{nA}, \mathrm{sA}, \mathrm{Af}$ & PIP (UN) & \\
\hline 318. Quamoclit angulata (Lam.) Bojer 둥근잎유홍초 & 1 & $\mathrm{nA}, \mathrm{sA}$ & IAP (NP) & $\mathrm{CS}$ \\
\hline 319. Quamoclit pennata (Desr.) Bojer 유홍초 & 1 & $\mathrm{nA}$ & PIP (CAP) & \\
\hline \multicolumn{5}{|l|}{ Boraginaceae 지치과 } \\
\hline 320. Amsinckia lycopsoides Lehm. 미국꽃말이 & 1 & $\mathrm{nA}$ & PIP (UN) & \\
\hline 321. Asperugo procumbens L. 갈퀴지치 & 1 & As, Eu & $\mathrm{IAP}(\mathrm{CAP})$ & PS \\
\hline 322. Myosotis alpestris F. W. Schmidt 고산물망초 & Pe. & $\mathrm{As}, \mathrm{Eu}$ & PIP (CAP) & \\
\hline 323. Myosotis scorpioides L. 물망초 & Pe. & As, Eu & PIP (CAP) & \\
\hline 324. Symphytum officinale L. 컴프리 & Pe. & As, Eu & IAP (NP) & MS \\
\hline \multicolumn{5}{|l|}{ Verbenaceae 마편초과 } \\
\hline 325. Verbena bonariensis L. 버들마편초 & Pe. & sA & IAP (NP) & PS \\
\hline 326. Verbena brasiliensis Vell. 브라질마편초 & Pe. & sA & IAP (NP) & PS \\
\hline \multicolumn{5}{|l|}{ Lamiaceae 꿀풀과 } \\
\hline 327. Dracocephalum moldavica L 향용머리 & 1 & As & $\mathrm{IAP}(\mathrm{CAP})$ & PS \\
\hline 328. Lamium purpureum L. 자주광대나물 & 2 & As, Eu & IAP (NP) & PS \\
\hline 329. Lamium purpureum L. var. hybridum (Vill.) Vill. 유럽광대나물 & 1 & $\mathrm{Eu}$ & $\mathrm{IAP}(\mathrm{CAP})$ & PS \\
\hline 330. Mentha pulegium L. 페니로얄민트 & Pe. & Af, As, Eu & PIP (CAP) & \\
\hline 331. Mentha spicata L. 녹양박하 & Pe. & As, Eu & $\mathrm{IAP}(\mathrm{CAP})$ & PS \\
\hline
\end{tabular}


Appendix 1. Continued.

\begin{tabular}{|c|c|c|c|c|}
\hline List & L-f & Orig. & Type of alien plant & Degree \\
\hline 332. Mentha $\times$ piperita L. 페퍼민트 & Pe. & As, Eu & PIP (CAP) & \\
\hline 333. Perilla frutescens (L.) Britton 들깨 & 1 & As & Arc. & \\
\hline 334. Perilla frutescens (L.) Britton var. crispa (Thunb.) H. Deane 소엽 & 1 & As & PIP (CAP) & \\
\hline 335. Salvia officinalis L. 살비아 & 1 & $\mathrm{Eu}$ & PIP (UN) & \\
\hline 336. Scutellaria baicalensis Georgi 황금 & Pe. & As & PIP (UN) & \\
\hline 337. Stachys agraria Schltdl. \& Cham. 애기석잠풀 & 1 & sA & IAP (CAP) & PS \\
\hline \multicolumn{5}{|l|}{ Solanaceae 가지과 } \\
\hline 338. Datura innoxia Mill. 털독말풀 & Pe. & $\mathrm{nA}$ & IAP (NP) & PS \\
\hline 339. Datura metel L. 흰독말풀 & 1 & $\mathrm{nA}$ & IAP (NP) & PS \\
\hline 340. Hyoscyamus niger L. 사리풀 & Pe. & As, Af & PIP (UN) & \\
\hline 341. Lycium chinense Mill. 구기자나무 & Tr. & As & Arc. & \\
\hline 342. Nicandra physalodes (L.) Gaertn. 페루꽈리 & 1 & sA & IAP (NP) & PS \\
\hline 343. Petunia × atkinsiana (Sweet) D. Don ex W. H. Baxter 페투니아 & Pe. & sA & PIP (CAP) & \\
\hline 344. Physalis acutifolia (Miers) Sandwith 노란꽃땅꽈리 & 1 & $\mathrm{nA}$ & IAP (NP) & PS \\
\hline 345. Physalis alkekengi L. 꽈리 & Pe. & $\mathrm{As}, \mathrm{Eu}$ & PIP (CAP) & \\
\hline 346. Physalis angulata L. 땅꽈리 & 1 & $\mathrm{nA}, \mathrm{sA}$ & IAP (NP) & MS \\
\hline 347. Physalis lagascae Roem. \& Schult. 노랑꽃누운땅꽈리 & 1 & sA & $\mathrm{IAP}(\mathrm{CAP})$ & PS \\
\hline 348. Solanum americanum Mill. 미국까마중 & 1 & $\mathrm{nA}, \mathrm{sA}$ & IAP (NP) & MS \\
\hline 349. Solanum carolinense L. 도깨비가지 & Pe. & $\mathrm{nA}$ & IAP (NP) & MS \\
\hline 350. Solanum elaeagnifolium Cav. 은빛까마중 & Pe. & $\mathrm{nA}, \mathrm{sA}$ & IAP (CAP) & PS \\
\hline 351. Solanum lycopersicum L. 토마토 & Pe. & sA & PIP (CAP) & \\
\hline 352. Solanum nigrum L. 까마중 & Pe. & $\mathrm{Af}, \mathrm{Eu}$ & Arc. & \\
\hline 353. Solanum pseudocapsicum L. 옥천앵두 & Pe. & sA & PIP (CAP) & \\
\hline 354. Solanum rostratum Dunal 가시가지 & 1 & $\mathrm{nA}$ & PIP (UN) & \\
\hline 355. Solanum sarrachoides Sendtn. 털까마중 & 1 & sA & IAP (NP) & PS \\
\hline 356. Solanum sisymbriifolium Lam. 둥근가시가지 & 1 & sA & PIP (UN) & \\
\hline 357. Solanum viarum Dunal 왕도깨비가지 & Pe. & sA & IAP (NP) & PS \\
\hline 358. Solanum villosum Mill. 노랑까마중 & 1 & Af, As, Eu & PIP (UN) & \\
\hline \multicolumn{5}{|l|}{ Scrophulariaceae 현삼과 } \\
\hline 359. Cymbalaria muralis P. Gaertn. \& B. Mey. \& Scherb. 덩굴해란초 & 1 & $\mathrm{Eu}$ & IAP (CAP) & PS \\
\hline 360. Gratiola neglecta Torr. 미국큰고추풀 & 1 & $\mathrm{nA}$ & $\mathrm{IAP}(\mathrm{CAP})$ & PS \\
\hline 361. Gratiola officinalis L. 유럽큰고추풀 & Pe. & As, Eu & PIP (UN) & \\
\hline 362. Lindernia dubia (L.) Pennell 미국외풀 & 1 & $\mathrm{nA}, \mathrm{sA}$ & IAP (NP) & PS \\
\hline 363. Linderniadubia(L.)Pennell. var.anagallidea(Michx)Cooper. 가는미국외풀 & 1 & $\mathrm{nA}, \mathrm{sA}$ & IAP (NP) & PS \\
\hline 364. Paulownia tomentosa (Thunb.) Steud. 참오동나무 & Tr. & As & PIP (CAP) & \\
\hline 365. Verbascum thapsus L. 우단담배풀 & 2 & As, Eu & IAP (NP) & PS \\
\hline 366. Veronica americana Schwein. 미국물칭개 & 2 & $\mathrm{nA}, \mathrm{As}$ & IAP (NP) & PS \\
\hline 367. Veronica anagallis-aquatica L. 큰물칭 개나물 & Pe. & As, Eu & IAP (CAP) & $\mathrm{CS}$ \\
\hline 368. Veronica arvensis L. 선개불알풀 & 1 & Af, As, Eu & IAP (NP) & WS \\
\hline 369. Veronica hederifolia L. 눈개불알풀 & 2 & As, Eu & IAP (NP) & PS \\
\hline
\end{tabular}


Appendix 1. Continued.

\begin{tabular}{|c|c|c|c|c|}
\hline List & L-f & Orig. & Type of alien plant & Degree \\
\hline 370. Veronica persica Poir. 큰개불알풀 & 2 & As & IAP (NP) & WS \\
\hline 371. Veronica peregrina L. 문모초 & 2 & $\mathrm{nA}, \mathrm{sA}$ & IAP (NP) & PS \\
\hline 372. Veronica polita Fr. 개불알풀 & 1 & Af, As, Eu & IAP (NP) & PS \\
\hline 373. Veronica serpyllifolia $\mathrm{L}$. 좀개불알풀 & Pe. & Eu, Af & IAP (NP) & PS \\
\hline \multicolumn{5}{|l|}{ Bignoniaceae 능소화과 } \\
\hline 374. Catalpa bignonioides Walter 꽃개오동 & Tr. & $\mathrm{nA}$ & PIP (CAP) & \\
\hline 375. Catalpa ovata G. Don 개오동 & Tr. & As & PIP (CAP) & \\
\hline 376. Catalpa bungei C. A. Mey 미국개오동 & Tr. & $\mathrm{nA}$ & PIP (CAP) & \\
\hline \multicolumn{5}{|l|}{ Pedaliaceae 참깨과 } \\
\hline 377. Sesamum indicum L. 참깨 & 1 & As & PIP (CAP) & \\
\hline \multicolumn{5}{|l|}{ Plantaginaceae 질경이과 } \\
\hline 378. Antirrhinum majus L. 금어초 & Pe. & Af, As, Eu & PIP (CAP) & \\
\hline 379. Digitalis lanata Ehrh. 라나타종꽃 & Pe. & As, Eu & PIP (CAP) & \\
\hline 380. Digitalis purpurea L. 디기탈리스 & Pe. & $\mathrm{Eu}$ & PIP (CAP) & \\
\hline 381. Linaria bipartita (Vent.) Willd. 애기금어초 & 2 & $\mathrm{nA}$ & PIP (CAP) & \\
\hline 382. Linaria vulgaris Mill. 좁은잎해란초 & Pe. & As, Eu & PIP (CAP) & \\
\hline 383. Nuttallanthus canadensis (L.) D. A. Sutton 솔잎해란초 & 1 & $\mathrm{nA}$ & $\mathrm{IAP}(\mathrm{CAP})$ & PS \\
\hline 384. Plantago aristata Michx 긴포꽃질경이 & 1 & $\mathrm{nA}$ & IAP (CAP) & PS \\
\hline 385. Plantago lanceolata L. 창질경이 & Pe. & $\mathrm{As}, \mathrm{Eu}$ & IAP (NP) & MS \\
\hline 386. Plantago virginica L. 미국질경이 & 2 & $\mathrm{nA}$ & IAP (NP) & PS \\
\hline \multicolumn{5}{|l|}{ Caprifoliaceae 인동과 } \\
\hline 387. Diervilla sessilifolia Buckley 애기병꽃 & Pe. & $\mathrm{nA}$ & PIP (CAP) & \\
\hline 388. Sambucus canadensis L. 캐나다딱총나무 & Pe. & $\mathrm{nA}$ & PIP (CAP) & \\
\hline 389. Sambucus nigra L. 서양딱총나무 & Pe. & $\mathrm{Eu}$ & IAP (CAP) & PS \\
\hline \multicolumn{5}{|l|}{ Valerianaceae 마타리과 } \\
\hline 390. Valerianella locusta (L.) Betcke 상치아재비 & 1 & $\mathrm{Eu}$ & IAP (NP) & PS \\
\hline \multicolumn{5}{|l|}{ Campanulaceae 초롱꽃과 } \\
\hline 391. Lobelia inflata L. 로베리아 & 1 & $\mathrm{nA}$ & PIP (CAP) & \\
\hline 392. Triodanis perfoliata (L.) Nieuwl. 비너스도라지 & 1 & $\mathrm{nA}$ & IAP (CAP) & PS \\
\hline \multicolumn{5}{|l|}{ Asteraceae 국화과 } \\
\hline 393. Achillea millefolium L. 서양톱풀 & Pe. & $\mathrm{nA}, \mathrm{As}, \mathrm{Eu}$ & IAP (NP) & MS \\
\hline 394. Ageratina altissima (L.) R. M. King \& H. Rob. 서양등골나물 & Pe. & $\mathrm{nA}$ & IAP (NP) & PS \\
\hline 395. Ageratum conyzoides L. 등골나물아재비 & 1 & $\mathrm{nA}$ & IAP (NP) & PS \\
\hline 396. Ageratum houstonianum Mill. 불로화 & Pe. & nA & IAP (CAP) & PS \\
\hline 397. Ambrosia artemisiifolia L. 돼지풀 & 1 & $\mathrm{nA}$ & IAP (NP) & WS \\
\hline 398. Ambrosia trifida L. 단풍잎돼지풀 & 1 & $\mathrm{nA}$ & IAP (NP) & MS \\
\hline 399. Anthemis arvensis L. 길뚝개꽃 & 1 & As, Eu & IAP (NP) & PS \\
\hline 400. Anthemis cotula L. 개꽃아재비 & 1 & $\mathrm{As}, \mathrm{Eu}$ & IAP (NP) & PS \\
\hline 401. Arctium lappa L. 우엉 & Pe. & As, Eu & PIP (CAP) & \\
\hline 402. Argyranthemum frutescens (L.) Sch .Bip. 마가렛트 & 1 & $\mathrm{Eu}$ & PIP (CAP) & \\
\hline
\end{tabular}


Appendix 1. Continued.

\begin{tabular}{|c|c|c|c|c|}
\hline List & L-f & Orig. & Type of alien plant & Degree \\
\hline 403. Bellis perennis L. 데이지 & Pe. & $\mathrm{Eu}$ & PIP (CAP) & \\
\hline 404. Bidens frondosa L. 미국가막사리 & 1 & $\mathrm{nA}$ & IAP (NP) & WS \\
\hline 405. Bidens pilosa L. 울산도깨비바늘 & 1 & $\mathrm{nA}, \mathrm{sA}$ & IAP (NP) & MS \\
\hline 406. Bidens polylepis S. F .Blake 노랑도깨비바늘 & 1 & $\mathrm{nA}$ & $\mathrm{IAP}(\mathrm{CAP})$ & PS \\
\hline 407. Bidens subalternans DC. 왕도깨비바늘 & 1 & sA & IAP (CAP) & PS \\
\hline 408. Carduus crispus L. 지느러미엉겅퀴 & 2 & As, Eu & IAP (NP) & SS \\
\hline 409. Carduus nutans L. 사향엉겅퀴 & 2 & As, Eu & IAP (NP) & PS \\
\hline 410. Carthamus lanatus L. 송곳잎엉겅퀴 & Pe. & $\mathrm{Eu}$ & PIP (UN) & \\
\hline 411. Centaurea cyanus L. 수레국화 & 2 & $\mathrm{Eu}$ & IAP (NP) & PS \\
\hline 412. Cichorium endivia L. 꽃상치 & 2 & $\mathrm{Eu}$ & PIP (CAP) & \\
\hline 413. Cirsium arvense (L.) Scop. 카나다엉겅퀴 & Pe. & $\mathrm{Eu}, \mathrm{Af}$ & PIP (UN) & \\
\hline 414. Cirsium vulgare (Savi) Ten. 서양가시엉겅퀴 & 2 & As, Eu & IAP (NP) & PS \\
\hline 415. Conyza bonariensis (L.) Cronquist 실 망초 & 2 & sA & IAP (NP) & SS \\
\hline 416. Conyza canadensis (L.) Cronquist 망초 & 2 & $\mathrm{nA}, \mathrm{sA}$ & IAP (NP) & WS \\
\hline 417. Coreopsis basalis (A. Dietr.) S. F. Blake 금계국 & 1 & $\mathrm{nA}$ & PIP (CAP) & \\
\hline 418. Coreopsis lanceolata L. 큰금계국 & Pe. & $\mathrm{nA}$ & IAP (NP) & $\mathrm{CS}$ \\
\hline 419. Coreopsis tinctoria Nutt. 기생초 & 1 & $\mathrm{nA}$ & IAP (NP) & MS \\
\hline 420. Cosmos bipinnatus Cav. 코스모스 & 1 & $\mathrm{nA}$ & IAP (NP) & $\mathrm{CS}$ \\
\hline 421. Cosmos sulphureus Cav. 노랑코스모스 & 1 & $\mathrm{nA}$ & IAP (NP) & PS \\
\hline 422. Cotula australis Hook.f. 유럽 단추쑥 & Pe. & Af, Oc, Eu & $\mathrm{IAP}(\mathrm{CAP})$ & PS \\
\hline 423. Crassocephalum crepidioides (Benth.) S. Moore 주홍서나물 & 1 & Af & IAP (NP) & CS \\
\hline 424. Crepis tectorum L. 나도민들레 & 1 & $\mathrm{As}, \mathrm{Eu}$ & IAP (NP) & PS \\
\hline 425. Dracopis amplexicaulis (Vahl) Cass. 천인국아재비 & 1 & $\mathrm{nA}$ & PIP (UN) & \\
\hline 426. Eclipta prostrata (L.) L. 한련초 & 1 & $\mathrm{nA}, \mathrm{sA}$ & Arc. & \\
\hline 427. Erechtites hieraciifolius (L.) Raf. ex DC. 붉은서나물 & 1 & $\mathrm{nA}, \mathrm{sA}$ & IAP (NP) & WS \\
\hline 428. Erigeron annuus (L.) Pers. 개망초 & 2 & $\mathrm{nA}$ & IAP (NP) & WS \\
\hline 429. Erigeron floribundus (Kunth) Sch. Bip. 큰망초 & 2 & sA & IAP (NP) & MS \\
\hline 430. Erigeron philadelphicus L. 봄망초 & Pe. & $\mathrm{nA}$ & IAP (NP) & PS \\
\hline 431. Erigeron strigosus Muhl. ex Willd. 주걱개망초 & 2 & $\mathrm{nA}$ & IAP (NP) & MS \\
\hline 432. Euthamia graminifolia (L.) Nutt. 미역취아재비 & Pe. & $\mathrm{nA}$ & IAP (CAP) & PS \\
\hline 433. Gaillardia aristata Pursh 까실천인국 & Pe. & $\mathrm{nA}$ & PIP (CAP) & \\
\hline 434. Gaillardia pulchella Foug. 인디언천인국 & 1 & $\mathrm{nA}$ & PIP (CAP) & \\
\hline 435. Galinsoga parviflora Cav. 별꽃아재비 & 1 & $\mathrm{nA}, \mathrm{sA}$ & IAP (NP) & MS \\
\hline 436. Galinsoga quadriradiata Ruiz \& Pav. 털별꽃아재비 & 1 & $\mathrm{nA}, \mathrm{sA}$ & IAP (NP) & WS \\
\hline 437. Gamochaeta calviceps (Fernald) Cabrera 선풀솜나물 & 2 & sA & IAP (NP) & PS \\
\hline 438. Gamochaeta pensylvanica (Willd.) Cabrera 미국풀솜나물 & 1 & $\mathrm{nA}, \mathrm{sA}$ & $\mathrm{IAP}(\mathrm{CAP})$ & PS \\
\hline 439. Gamochaeta purpurea (L.) Cabrera 자주풀솜나물 & 1 & $\mathrm{nA}$ & IAP (NP) & PS \\
\hline 440. Helianthus debilis Nutt. 애기해바라기 & Pe. & $\mathrm{nA}$ & IAP (NP) & PS \\
\hline 441. Helianthus tuberosus L. 뚱딴지 & Pe. & $\mathrm{nA}$ & IAP (NP) & MS \\
\hline 442. Heliopsis helianthoides (L.) Sweet 하늘바라기 & Pe. & $\mathrm{nA}$ & PIP (CAP) & \\
\hline
\end{tabular}


Appendix 1. Continued.

\begin{tabular}{|c|c|c|c|c|}
\hline List & L-f & Orig. & Type of alien plant & Degree \\
\hline 443. Hieracium caespitosum Dumort. 유럽조밥나물 & Pe. & As, Eu & IAP (NP) & PS \\
\hline 444. Hypochaeris radicata $\mathrm{L}$. 서양금혼초 & Pe. & As, Eu & IAP (NP) & MS \\
\hline 445. Lactuca saligna L. 가는잎가시상추 & Pe. & Af, As, Eu & IAP (CAP) & PS \\
\hline 446. Lactuca serriola L. 가시상추 & 2 & Af, As, Eu & IAP (NP) & PS \\
\hline 447. Lapsana communis L. 서양개보리 뺑이 & 1 & As, Eu & IAP (NP) & PS \\
\hline 448. Leucanthemum vulgare Lam. 불란서국화 & Pe. & As, Eu & IAP (NP) & PS \\
\hline 449. Matricaria chamomilla L 카밀 레 & 1 & As, Eu & PIP (CAP) & \\
\hline 450. Matricaria inodora L. 꽃족제비쑥 & 2 & $\mathrm{As}, \mathrm{Eu}$ & PIP (UN) & \\
\hline 451. Matricaria discoidea $\mathrm{DC}$ 족제비쑥 & 1 & $\mathrm{nA}$ & IAP (NP) & PS \\
\hline 452. Parthenium hysterophorus L. 돼지풀아재비 & 1 & $\mathrm{nA}, \mathrm{sA}$ & IAP (NP) & PS \\
\hline 453. Rudbeckia bicolor Nutt. 원추천인국 & Pe. & $\mathrm{nA}$ & IAP (NP) & $\mathrm{CS}$ \\
\hline 454. Rudbeckia hirta L. 수잔루드베키아 & Pe. & $\mathrm{nA}$ & IAP (NP) & PS \\
\hline 455. Rudbeckia laciniata L. 삼잎국화 & Pe. & $\mathrm{nA}$ & IAP (NP) & PS \\
\hline 456. Rudbeckia laciniata L. var. hortensia L. H. Bailey 겹삼잎국화 & Pe. & $\mathrm{nA}$ & IAP (NP) & PS \\
\hline 457. Senecio inaequidens DC. 가는잎금방망이 & Pe. & Af & IAP (CAP) & PS \\
\hline 458. Senecio scandens Buch.-Ham. ex D. Don 양재금방망이 & Pe. & As & IAP (CAP) & PS \\
\hline 459. Senecio vulgaris L. 개쑥갓 & 1 & $\mathrm{As}, \mathrm{Eu}$ & IAP (NP) & SS \\
\hline 460. Silphium perfoliatum L. 실피움퍼르폴리아툼 & Pe. & $\mathrm{nA}$ & PIP (CAP) & \\
\hline 461. Silybum marianum (L.) Gaertn. 흰무늬엉겅퀴 & 2 & Af, As, Eu & PIP (CAP) & \\
\hline 462. Solidago altissima L. 양미역취 & Pe. & $\mathrm{nA}$ & IAP (NP) & PS \\
\hline 463. Solidago gigantea Aiton 미국미역취 & Pe. & nA & IAP (NP) & $\mathrm{CS}$ \\
\hline 464. Sonchus asper (L.) Hill 큰방가지똥 & 1 & Af, As, Eu & IAP (NP) & SS \\
\hline 465. Sonchus oleraceus L. 방가지똥 & 1 & As, Eu & IAP (NP) & SS \\
\hline 466. Sonchus palustris L. 사라구 & Pe. & As, Eu & PIP (CAP) & \\
\hline 467. Symphyotrichum expansum (Poepp.exSpreng)GL.Nesom 큰비짜루국화 & 1 & $\mathrm{nA}$ & IAP (NP) & PS \\
\hline 468. Symphyotrichum novi-belgii (L.) G. L. Nesom 우선국 & Pe. & $\mathrm{nA}$ & PIP (UN) & \\
\hline 469. Symphyotrichum pilosum (Willd.) G. L. Nesom 미국쑥부쟁이 & Pe. & nA & IAP (NP) & SS \\
\hline 470. Symphyotrichum subulatum (Michx.) G. L. Nesom 비짜루국화 & 1 & $\mathrm{nA}, \mathrm{sA}$ & IAP (NP) & $\mathrm{CS}$ \\
\hline 471. Tagetes erecta L. 천수국 & 1 & nA & PIP (CAP) & \\
\hline 472. Tagetes minuta L. 만수국아재비 & 1 & sA & IAP (NP) & MS \\
\hline 473. Tanacetum cinerariifolium (Trevir.) Sch. Bip. 제충국 & Pe. & $\mathrm{Eu}$ & PIP (CAP) & \\
\hline 474. Taraxacum erythrospermum Andrz. ex Besser 붉은씨서양민들레 & Pe. & As, Eu & IAP (NP) & PS \\
\hline 475. Taraxacum officinale F. H. Wigg. 서양민들레 & Pe. & $\mathrm{Eu}$ & IAP (NP) & WS \\
\hline 476. Tragopogon dubius Scop. 쇠채아재비 & 2 & As, Eu & IAP (NP) & PS \\
\hline 477. Verbesina alternifolia (L.) Britton ex Kearney 나래가막사리 & Pe. & $\mathrm{nA}$ & IAP (NP) & PS \\
\hline 478. Xanthium italicum Moretti 가시도꼬마리 & 1 & $\mathrm{nA}, \mathrm{sA}$ & IAP (NP) & PS \\
\hline 479. Xanthium orientale L. 큰도꼬마리 & 1 & $\mathrm{nA}, \mathrm{sA}$ & IAP (NP) & MS \\
\hline 480. Xanthium spinosum L. 바늘도꼬마리 & Pe. & $\mathrm{nA}, \mathrm{sA}$ & IAP (NP) & PS \\
\hline 481. Xanthium strumarium L. 도꼬마리 & 1 & $\mathrm{nA}, \mathrm{sA}$ & Arc. & \\
\hline 482. Zinnia elegans Jacq. 백일홍 & 1 & $\mathrm{nA}$ & PIP (CAP) & \\
\hline
\end{tabular}


Appendix 1. Continued.

List

Alismataceae 택사과

483. Hydrocleysnymphoides(Humb.\&Bonpl.exWilld)Buchenau 물양귀비

Liliaceae 백합과

484. Allium tuberosum Rottler ex Spreng. 부추

\section{Asparagaceae 비짜루과}

485. Asparagus officinalis L. 아스파라거스

486. Yucca filamentosa L. 실유카

487. Yucca treculeana Carrière 육카나무

\section{Amaryllidaceae 수선화과}

488. Lycoris radiata (L'Hér.) Herb. 석산

489. Zephyranthes candida (Lindl.) Herb. 흰꽃나도사프란

\section{Pontederiaceae 물옥잠과}

490. Eichhornia crassipes (Mart.) Solms 부레옥잠

\section{Iridaceae 붓쫓과}

491. Iris pseudacorus L. 노랑꽃창포

492. Iris pumila L. 푸밀라붓꽃

493. Iris $\times$ germanica L. 독일붓꽃

494. Sisyrinchium rosulatum E. P. Bicknell 등심붓꽃

495. Sisyrinchium micranthum Cav. 연등심붓꽃

496. Tritonia $\times$ crocosmiiflora (Lemoine) G. Nicholson 애기범부채

\section{Commelinaceae 닭의장풀과}

497. Commelina benghalensis L. 고깔닭의장풀

498. Commelina diffusa Burm.f. 왕닭의장풀

499. Rohdea japonica (Thunb.) Roth 만년청

500. Tradescantia fluminensis Vell. 얼룩닭의장풀

501. Tradescantia ohiensis Raf. 자주달개비

502. Tradescantia spathacea $\mathrm{Sw}$. 자주만년청

\section{Poaceae 벼과}

503. Aegilops caudata L 비리새풀

504. Aegilops cylindrica Host 염소풀

505. Agrostis capillaris L. 들겨이삭

506. Agrostis stolonifera L. 애기겨이삭

507. Aira caryophyllea L. 은털새

508. Alopecurus geniculatus L. 유럽뚝새풀

509. Alopecurus japonicus Steud. 털뚝새풀

510. Alopecurus myosuroides Huds. 쥐꼬리뚝새풀

511. Alopecurus pratensis L. 큰뚝새풀

512. Andropogon virginicus L. 나도솔새

513. Anthoxanthum odoratum L. 향기풀

514. Arrhenatherum elatius (L.) P. Beauv. ex J. Presl \& C.Presl 개나래새

L-f

Orig.

Type of alien plant Degree

Pe. $\quad$ SA $\quad$ PIP (CAP)

Pe.

As

PIP (CAP)

Pe.

PIP (CAP)

Pe.

PIP (CAP)

Pe.

nA

PIP (CAP)

Pe.

As

PIP (CAP)

Pe.

sA

IAP (NP)

PS

Pe

sA

PIP (CAP)

Pe

Pe.

As, Eu

PIP (CAP)

Pe. $\quad \mathrm{Eu}$

PIP (CAP)

Pe.

PIP (CAP)

Pe. nA

IAP (NP) PS

Pe.

nA, sA

Pe.

Af

IAP (CAP) PS

IAP (NP) PS

Pe.

Pe.

Pe.

As, Af

IAP (CAP)

PS

IAP (CAP)

PS

Pe. As

PIP (CAP)

IAP (NP) PS

Pe. nA

IAP (NP)

MS

Pe.

sA

PIP (CAP)

PIP (UN)

IAP (NP) PS

IAP (CAP) PS

IAP (NP) PS

IAP (NP) PS

1 Af, As, Eu

Pe. Eu, Af

IAP (CAP) PS

1 As

IAP (NP) PS

1 As, Eu

IAP (NP) PS

Pe. As, Eu

IAP (NP) PS

Pe. nA, sA

IAP (NP) PS

Pe. Af, As, Eu

IAP (NP) PS

Pe. Af, As, Eu 
Appendix 1. Continued.

\begin{tabular}{|c|c|c|c|c|}
\hline List & L-f & Orig. & Type of alien plant & Degree \\
\hline 515. Arrhenatherum elatius (L.)P. Beauv. ex J. Presl \& C. Presl var. bulbosum Spenn. 염주개나래새 & Pe. & $\mathrm{Eu}$, Af & IAP (CAP) & PS \\
\hline 516. Arundo donax L. 물대 & Pe. & $\mathrm{As}, \mathrm{Eu}$ & PIP (CAP) & \\
\hline 517. Avena fatua L. 메귀리 & 2 & Af, As, Eu & IAP (NP) & MS \\
\hline 518. Avena sativa L. 귀리 & 2 & As & PIP (CAP) & \\
\hline 519. Briza minor L. 방울새풀 & 1 & As, Eu & IAP (NP) & PS \\
\hline 520. Bromus alopecuros Poir. 긴털참새귀리 & 1 & Eu & IAP (CAP) & PS \\
\hline 521. Bromus carinatus Hook. \& Arn. 성긴이삭풀 & Pe. & $\mathrm{nA}, \mathrm{sA}$ & IAP (NP) & PS \\
\hline 522. Bromus catharticus Vahl 큰이삭풀 & Pe. & sA & IAP (NP) & MS \\
\hline 523. Bromus commutatus Schrad. 털큰참새 귀리 & 2 & Af, As, Eu & IAP (CAP) & PS \\
\hline 524. Bromus hordeaceus L. 털참새귀리 & 2 & As, Eu & IAP (NP) & PS \\
\hline 525. Bromus inermis Leyss. 좀참새귀리 & Pe. & $\mathrm{As}, \mathrm{Eu}$ & IAP (NP) & PS \\
\hline 526. Bromus racemosus L. 민둥참새귀리 & Pe. & As, $\mathrm{Eu}$ & IAP (NP) & PS \\
\hline 527. Bromus rigidus Roth 긴까락빕새귀리 & 2 & As, Eu & IAP (NP) & PS \\
\hline 528. Bromus secalinus L. 큰참새귀리 & 2 & As, Eu & IAP (NP) & PS \\
\hline 529. Bromus sterilis L. 까락빕새 귀리 & 1 & As, Eu & IAP (NP) & PS \\
\hline 530. Bromus tectorum L. 털빕새귀리 & 2 & As, Eu & IAP (NP) & MS \\
\hline 531. Catapodium rigidum (L.) C.E.Hubb. 고사리새 & 1 & $\mathrm{As}, \mathrm{Eu}$ & IAP (NP) & PS \\
\hline 532. Cenchrus longispinus (Hack.) Fernald 대청가시풀 & 1 & $\mathrm{nA}$ & IAP (NP) & PS \\
\hline 533. Cenchrus latifolius (Spreng.) Morrone 나도강아지풀 & Pe. & sA & PIP (UN) & \\
\hline 534. Chasmanthium latifolium (Michx.) H. O.Yates 낚시귀리 & Pe. & $\mathrm{nA}$ & $\mathrm{IAP}(\mathrm{CAP})$ & PS \\
\hline 535. Chloris virgata $\mathrm{Sw}$. 나도바랭이 & 1 & $\mathrm{nA}, \mathrm{sA}$ & IAP (NP) & PS \\
\hline 536. Coix lacryma-jobi L. 염주 & 1 & As & IAP (NP) & PS \\
\hline 537. Coix lacryma-jobi L. var. ma-yuen (Rom. Caill.) Stapf 율무 & 1 & As & PIP (CAP) & \\
\hline 538. Cortaderia selloana (Schult. \& Schult.f.) Asch. \& Graebn. 팜파스그래스 & Pe. & sA & PIP (CAP) & \\
\hline 539. Cynosurus cristatus L. 빗살새 & Pe. & $\mathrm{As}, \mathrm{Eu}$ & PIP (UN) & \\
\hline 540. Cynosurus echinatus L. 좀빗살새 & 1 & As, Eu & $\operatorname{IAP}(\mathrm{CAP})$ & PS \\
\hline 541. Dactylis glomerata L. 오리새 & Pe. & $\mathrm{As}, \mathrm{Eu}$ & IAP (NP) & WS \\
\hline 542. Dactyloctenium aegyptium (L.) Willd. 지네 발새 & 1 & As, Af & IAP (NP) & PS \\
\hline 543. Danthonia spicata (L.) P. Beauv. ex Roem. \& Schult. 꼬인새 & Pe. & $\mathrm{nA}$ & $\mathrm{IAP}(\mathrm{CAP})$ & PS \\
\hline 544. Dichanthelium acuminatum (Sw.) Gould \& C. A. Clark 방석기장 & Pe. & $\mathrm{nA}, \mathrm{sA}$ & $\mathrm{IAP}(\mathrm{CAP})$ & PS \\
\hline 545. Echinochloa colonum (L.) Link 열대피 & Pe. & As, Af & IAP (CAP) & PS \\
\hline 546. Elymus repens (L.) Gould 구주개밀 & Pe. & Af, As, Eu & IAP (NP) & PS \\
\hline 547. Eragrostis curvula (Schrad.) Nees 능수참새그령 & Pe. & Af & IAP (NP) & MS \\
\hline 548. Eragrostis pectinacea (Michx.) Nees 들비노리 & 1 & $\mathrm{nA}, \mathrm{sA}$ & $\mathrm{IAP}(\mathrm{CAP})$ & PS \\
\hline 549. Eremochloa ophiuroides (Munro) Hack. 외대쇠치기아재비 & Pe. & As & IAP (NP) & PS \\
\hline 550. Festuca arundinacea Schreb. 큰김의털 & Pe. & Af, As, Eu & IAP (NP) & SS \\
\hline 551. Festuca heterophylla Lam. 사방김의털 & Pe. & $\mathrm{Eu}$ & IAP (NP) & PS \\
\hline 552. Festuca pratensis Huds. 넓은김의털 & Pe. & As, Eu & IAP (NP) & PS \\
\hline 553. Glyceria declinata Bréb. 유럽육절보리풀 & Pe. & $\mathrm{Eu}$ & IAP (CAP) & PS \\
\hline 554. Hainardia cylindrica (Willd.) Greuter 나도뿔이삭풀 & 1 & As, Eu & IAP (CAP) & PS \\
\hline
\end{tabular}


Appendix 1. Continued.

\begin{tabular}{|c|c|c|c|c|}
\hline List & L-f & Orig. & Type of alien plant & Degree \\
\hline 555. Holcus lanatus L. 흰털새 & Pe. & $\mathrm{Eu}$ & IAP (NP) & PS \\
\hline 556. Holcus mollis L. 긴흰털새 & Pe. & Af, Eu & PIP (UN) & \\
\hline 557. Hordeum jubatum L. 긴까락보리풀 & Pe. & $\mathrm{nA}, \mathrm{As}$ & IAP (NP) & PS \\
\hline 558. Hordeum murinum L. 보리풀 & 1 & $\mathrm{As}, \mathrm{Eu}$ & IAP (NP) & PS \\
\hline 559. Hordeum pusillum Nutt. 좀보리풀 & 1 & $\mathrm{nA}, \mathrm{sA}$ & IAP (NP) & PS \\
\hline 560. Hordeum vulgare L. 보리 & Pe. & As & PIP (CAP) & \\
\hline 561. Leptochloa fusca (L.) Kunth 갯드렁새 & 1 & $\mathrm{nA}, \mathrm{sA}, \mathrm{Af}, \mathrm{As}, \mathrm{Oc}$ & IAP (NP) & PS \\
\hline 562. Lolium multiflorum Lam. 쥐보리 & 2 & As, Eu & IAP (NP) & CS \\
\hline 563. Lolium perenne L. 호밀풀 & Pe. & Af, As, Eu & IAP (NP) & SS \\
\hline 564. Lolium rigidum Gaudin 댕돌보리 & 1 & As, Eu & $\mathrm{IAP}(\mathrm{CAP})$ & PS \\
\hline 565. Lolium temulentum L. 독보리 & 1 & As, Eu & PIP (UN) & \\
\hline 566. Muhlenbergia capillaris (Lam.) Trin. 핑크뮬리 & Pe. & $\mathrm{nA}, \mathrm{sA}$ & PIP (CAP) & \\
\hline 567. Panicum dichotomiflorum Michx. 미국개기장 & 1 & $\mathrm{nA}, \mathrm{sA}$ & IAP (NP) & SS \\
\hline 568. Panicum miliaceum L. 기장 & 1 & As & Arc. & \\
\hline 569. Panicum virgatum L. 큰개기장 & Pe. & $\mathrm{nA}, \mathrm{sA}$ & IAP (NP) & PS \\
\hline 570. Parapholis incurva (L.) C. E. Hubb. 뿔이삭풀 & 1 & As, Eu & IAP (NP) & PS \\
\hline 571. Paspalum dilatatum Poir. 큰참새피 & Pe. & sA & IAP (NP) & PS \\
\hline 572. Paspalum distichum L. 물참새피 & Pe. & $\mathrm{nA}, \mathrm{sA}$ & IAP (NP) & PS \\
\hline 573. Paspalum notatum Flugge 민둥참새피 & Pe. & sA & IAP (CAP) & PS \\
\hline 574. Paspalum urvillei Steud. 털큰참새피 & Pe. & sA & IAP (CAP) & PS \\
\hline 575. Pennisetum flaccidum Griseb. 가는수크령 & Pe. & As & IAP (CAP) & PS \\
\hline 576. Phalaris canariensis L. 카나리새풀 & 1 & $\mathrm{Eu}$ & IAP (NP) & PS \\
\hline 577. Phalaris minor Retz. 애기카나리새풀 & 1 & As, Eu & PIP (UN) & \\
\hline 578. Phalaris paradoxa L. 날개카나리새풀 & 1 & As, Eu & $\mathrm{IAP}(\mathrm{CAP})$ & PS \\
\hline 579. Phleum paniculatum Huds. 작은조아재비 & 1 & As, Eu & IAP (CAP) & PS \\
\hline 580. Phleum pratense L. 큰조아재비 & Pe. & $\mathrm{As}, \mathrm{Eu}$ & IAP (NP) & CS \\
\hline 581. Phyllostachys edulis (Carrière) J. Houz. 죽순대 & Pe. & As & PIP (CAP) & \\
\hline 582. Phyllostachys nigra (Lodd. ex Lindl.) Munro 오죽 & Pe. & As & PIP (CAP) & \\
\hline 583. Phyllostachys reticulata (Rupr.) K. Koch 왕대 & Pe. & As & PIP (CAP) & \\
\hline 584. Poa bulbosa L. 개이삭포아풀 & Pe. & As, $\mathrm{Eu}$ & IAP (CAP) & PS \\
\hline 585. Poa bulbosa L. subsp. vivipara (Koeler) Arcang. 이삭포아풀 & Pe. & Af, As, Eu & IAP (NP) & PS \\
\hline 586. Poa compress $a$ L. 좀포아풀 & Pe. & As, Eu & IAP (NP) & MS \\
\hline 587. Poa pratensis L. 왕포아풀 & Pe. & $\mathrm{nA}, \mathrm{As}, \mathrm{Eu}$ & IAP (NP) & SS \\
\hline 588. Poa trivialis L. 큰새포아풀 & Pe. & $\mathrm{Af}, \mathrm{Eu}$ & IAP (NP) & PS \\
\hline 589. Puccinellia distans (Jacq.) Parl. 처진미꾸리광이 & Pe. & As, Eu & IAP (CAP) & PS \\
\hline 590. Rottboellia cochinchinensis (Lour.) Clayton 개쇠치기풀 & 1 & As, Af, Oc & IAP (CAP) & PS \\
\hline 591. Saccharum arundinaceum Retz. 큰개사탕수수 & Pe. & As & IAP (CAP) & PS \\
\hline 592. Saccharum spontaneum L. 개사탕수수 & Pe. & As, Oc & IAP (NP) & PS \\
\hline 593. Secale cereale L. 호밀 & 2 & As & PIP (CAP) & \\
\hline 594. Setaria verticillata (L.) P. Beauv. 유럽강아지풀 & 1 & Af, As, Eu, Oc & PIP (UN) & \\
\hline
\end{tabular}


Appendix 1. Continued.

\begin{tabular}{|c|c|c|c|c|}
\hline List & L-f & Orig. & Type of alien plant & Degree \\
\hline 595. Sorghum bicolor (L.) Moench 수수 & Pe. & Af & PIP (CAP) & \\
\hline 596. Sorghum halepense (L.) Pers. 시리아수수새 & Pe. & As, Eu & IAP (NP) & PS \\
\hline 597. Spartina alterniflora Loisel. 갯쥐꼬리풀 & Pe. & $\mathrm{nA}, \mathrm{sA}$ & IAP (CAP) & PS \\
\hline 598. Spartina anglica C. E. Hubb. 영국갯근풀 & Pe. & $\mathrm{Eu}, \mathrm{Oc}$ & IAP (CAP) & PS \\
\hline 599. Vulpia bromoides (L.) Gray 들묵새아재비 & 1 & $\mathrm{Eu}$ & $\mathrm{IAP}(\mathrm{CAP})$ & PS \\
\hline 600. Vulpia myuros (L.) C. C. Gmel. 들묵새 & 1 & Af, As, Eu & IAP (NP) & MS \\
\hline 601. Vulpia myuros (L.) C. C. Gmel. subsp. megalura (Nutt.) Soják 큰묵새 & 1 & $\mathrm{nA}$ & PIP (UN) & \\
\hline 602. Zoysia matrella (L.) Merr. 금잔디 & Pe. & As, Eu & IAP (CAP) & PS \\
\hline \multicolumn{5}{|l|}{ Arecaceae 야자나무과 } \\
\hline 603. Trachycarpus fortunei (Hook.) H. Wendl. 종려나무 & Tr. & As & PIP (CAP) & \\
\hline \multicolumn{5}{|l|}{ Araceae 천남성과 } \\
\hline 604. Amorphophallus konjac K. Koch 곤약 & Pe. & As & PIP (CAP) & \\
\hline 605. Pistia stratiotes L. 물상추 & Pe. & $\mathrm{nA}, \mathrm{sA}, \mathrm{As}, \mathrm{Af}, \mathrm{Oc}$ & IAP (CAP) & PS \\
\hline \multicolumn{5}{|l|}{ Lemnaceae 개구리밥과 } \\
\hline 606. Spirodela punctata (G. Mey.) C. H. Thomps. 점개구리밥 & Pe. & sA & IAP (CAP) & PS \\
\hline 607. Wolffia arrhiza (L.) Horkel ex Wimm. 분개구리밥 & Pe. & Af, As, Eu & PIP (CAP) & \\
\hline \multicolumn{5}{|l|}{ Butomaceae 부토마과 } \\
\hline 608. Butomus umbellatus L. 꽃골풀 & Pe. & As, Eu & PIP (CAP) & \\
\hline \multicolumn{5}{|l|}{ Cyperaceae 사초과 } \\
\hline 609. Carex brevior (Dewey) Mack. Ex Lunell 작은비사초 & Pe. & nA & IAP (CAP) & PS \\
\hline 610. Carex hirsutella Mack 미국산사초 & Pe. & $\mathrm{nA}$ & IAP (CAP) & PS \\
\hline 611. Carex muehlenbergii Schkuhr ex Willd. 미국타래사초 & Pe. & $\mathrm{nA}, \mathrm{sA}$ & IAP (CAP) & PS \\
\hline 612. Carex scoparia Schkuhr ex Willd. 한석사초 & Pe. & $\mathrm{nA}$ & IAP (CAP) & PS \\
\hline 613. Cyperus eragrostis Lam. 열 대방동사니 & Pe. & $\mathrm{nA}, \mathrm{sA}$ & IAP (CAP) & PS \\
\hline 614. Cyperus esculentus L. 기름골 & Pe. & $\mathrm{nA}, \mathrm{sA}, \mathrm{As}, \mathrm{Eu}$ & IAP (CAP) & PS \\
\hline 615. Cyperus exaltatus Retz. var. iwasakii (Makino) T. Koyama 왕골 & Pe. & sA, Af, As & Arc. & \\
\hline \multicolumn{5}{|l|}{ Zingiberaceae 생강과 } \\
\hline 616. Hedychium coronarium J. Koenig 꽃생강 & Pe. & As & PIP (CAP) & \\
\hline 617. Zingiber mioga (Thunb.) Roscoe 양하 & Pe. & As & IAP (NP) & PS \\
\hline \multicolumn{5}{|l|}{ Cannaceae 홍초과 } \\
\hline 618. Canna $\times$ generalis L. H. Bailey 칸나 & Pe. & sA & IAP (CAP) & PS \\
\hline \multicolumn{5}{|l|}{ Marantaceae 마란타과 } \\
\hline 619. Thalia dealbata Fraser ex Roscoe 워터칸나 & Pe. & $\mathrm{nA}$ & PIP (CAP) & \\
\hline
\end{tabular}

L-f, life form; Orig., origin; 1, annual; 2, biennial; Pe., perennial; Tr., tree As, Asia; nA, North America; sA, South America; Eu, Europe; Af, Africa; Oc, Oceania; Arc., archaeophyte; PIP (CAP), concerned alien plant; PIP (UN), uncertain plant; IAP (CAP), casual alien plant; IAP (NP), naturalized plant; WS, widespread; SS, serious spread; CS, concerned spread; MS, minor spread; PS, potential sprerad. 